The University of San Francisco

USF Scholarship: a digital repository @ Gleeson Library | Geschke Center

January 2008

\title{
Defining Information Systems as Work Systems: Implications for the IS Field
}

Steven Alter

University of San Francisco, alter@usfca.edu

Follow this and additional works at: http://repository.usfca.edu/at

Part of the Business Administration, Management, and Operations Commons, Management $\underline{\text { Information Systems Commons, and the Technology and Innovation Commons }}$

\section{Recommended Citation}

Alter, Steven, "Defining Information Systems as Work Systems: Implications for the IS Field" (2008). Business Analytics and Information Systems. Paper 22.

http://repository.usfca.edu/at/22 


\title{
Defining Information Systems as Work Systems: Implications for the IS Field
}

\author{
Steven Alter \\ University of San Francisco \\ School of Business and Management \\ San Francisco, CA, U.S.A. \\ E-mail: alter@usfca.edu
}

Revised and published in European Journal of Information Systems, 17(5), Oct. 2008, pp. 448469

\begin{abstract}
The lack of an agreed upon definition of information system is one of many obstacles troubling the academic information systems discipline. After listing a number of definitions of IS, this paper defines information system as a special case of work system as defined in Alter (1999a). This definition has many desirable characteristics: It is easy to understand; differentiates IS from IT; covers totally manual, partially automated, and totally automated information systems; links to a life cycle model that generates many insights about development and implementation problems; provides a simple guideline that helps in interpreting common IS/IT jargon; and has other useful implications related to IS concepts, IS terminology, and the analysis and design of information systems. The paper presents the proposed IS definition and evaluates the definition in terms of simplicity, clarity, scope, systematic power, explanatory power, validity, reliability, and fruitfulness. An Appendix summarizes previously published concepts and two frameworks that flow from the proposed definition and are useful for appreciating many points in the evaluation section.
\end{abstract}

\section{The Challenge of Defining Information System}

In an EJIS editorial, Ray Paul (2007) identified five challenges related to the state of the information systems discipline. One of those challenges was to produce a definition of the term information system. Many definitions have been proposed over the years by researchers and textbook authors, but most are viewed as unsatisfactory for one reason or another. 
One of the reasons for the dissatisfaction is that the term information system is used to refer to different types of objects that have many aspects in common. Carvalho (2000) identifies four types of objects that can be viewed as information systems:

IS1: Organisations (autonomous systems) whose business (purpose) is to provide information to their clients.

IS2: A sub-system that exists in any system that is capable of governing itself (autonomous system). The information system (IS2) assures the communication between the managerial and operational sub-systems of an organisation - that's its purpose. When this communication is asynchronous, a memory to store the messages is necessary. IS2 includes such memory.

IS3: Any combination of active objects (processors) that deal only with symbolic objects (information) and whose agents are computers or computer-based devices - a computer-based system.

IS4: Any combination of active objects (processors) that deal only with symbolic objects (information).

He says that the four types of objects "all deal with information; they all are somewhat related to organisations or to the work carried out in organisations; and they all are related to information technology, either because they can benefit from its use or because they are made with computers or computer-based devices." Table 1 lists a number of IS definitions that represent or combine the different views of the type of object that is being discussed. These definitions are listed more or less in order based on the extent to which the definition emphasizes social or organizational concerns versus technical or mathematical concerns.

Table 1 Alternative definitions of information system

\begin{tabular}{|l|l|}
\hline \multicolumn{1}{|c|}{ Source } & \multicolumn{1}{c|}{ Definition } \\
\hline $\begin{array}{l}\text { F. Land (1985, p. } \\
\text { 215), cited by } \\
\text { Magalhães (1999, } \\
\text { p. 6) }\end{array}$ & $\begin{array}{l}\text { "An information system is a social system, which has embedded in } \\
\text { technology plays a part is increasing rapidly. But this does not } \\
\text { prevent the overall system from being a social system, and it is not } \\
\text { possible to design a robust, effective information system, } \\
\text { incorporating significant amounts of the technology without } \\
\text { treating it as a social system." }\end{array}$ \\
\hline $\begin{array}{l}\text { Symons (1991, } \\
\text { pp. 186-187), } \\
\text { cited by } \\
\begin{array}{l}\text { Magalhães (1999, } \\
\text { p. 6) }\end{array}\end{array}$ & $\begin{array}{l}\text { An information system is "a complex social object which results } \\
\text { from the embedding of computer systems into an organization ... } \\
\text { where it is not possible to separate the technical from the social } \\
\text { influenced by cultural values, political interests and participants" } \\
\text { particular definitions of their situations intervening in the }\end{array}$ \\
\hline
\end{tabular}




\begin{tabular}{|c|c|}
\hline & implementation of such a system." \\
\hline $\begin{array}{l}\text { Paul (2007, pp. } \\
\text { 194-195) }\end{array}$ & $\begin{array}{l}\text { The IS is what emerges from the usage that is made of the IT } \\
\text { delivery system by users (whose strengths are that they are human } \\
\text { beings, not machines). This usage will be made up of two parts: } 1 \text {. } \\
\text { First the formal processes, which are currently usually assumed to } \\
\text { be pre-determinable with respect to decisions about what IT to } \\
\text { use. ... 2. Second, the informal processes, which are what the } \\
\text { human beings who use the IT and the formal processes create or } \\
\text { invent in order to ensure that useful work is done." }\end{array}$ \\
\hline $\begin{array}{l}\text { Davis }(2000, p . \\
67)\end{array}$ & $\begin{array}{l}\text { "A simple definition might be that an information system is a } \\
\text { system in the organization that delivers information and } \\
\text { communication services needed by the organization." } \\
\text { "This can be expanded to describe the system more fully. The } \\
\text { information system or management information system of an } \\
\text { organization consists of the information technology infrastructure, } \\
\text { application systems, and personnel that employ information } \\
\text { technology to deliver information and communication services for } \\
\text { transaction processing/ operations and administration/ management } \\
\text { of an organization. The system utilizes computer and } \\
\text { communications hardware and software, manual procedures, and } \\
\text { internal and external repositories of data. The systems apply a } \\
\text { combination of automation coming human actions and user } \\
\text { machine interaction." }\end{array}$ \\
\hline $\begin{array}{l}\text { Lyytinen \& } \\
\text { Newman }(2006, \\
\text { p. 4) }\end{array}$ & $\begin{array}{l}\text { "an organizational system that consists of technical, organizational } \\
\text { and semiotic elements which are all re-organized and expanded } \\
\text { during ISD [information system development] to serve an } \\
\text { organizational purpose.". }\end{array}$ \\
\hline $\begin{array}{l}\text { Buckingham et al } \\
(1987, \text { p. } 18) \\
\text { cited by Avison } \\
\& \text { Myers (1995) }\end{array}$ & $\begin{array}{l}\text { "A system which assembles, stores, processes and delivers } \\
\text { information relevant to an organization (or to society) in such a way } \\
\text { that the information is accessible and useful to those who wish to } \\
\text { use it, including managers, staff, clients and citizens. An } \\
\text { information system is a human activity (social) system which may } \\
\text { or may not involve computer systems." }\end{array}$ \\
\hline $\begin{array}{l}\text { UKAIS, United } \\
\text { Kingdom } \\
\text { Academy for } \\
\text { Information } \\
\text { Systems (1997) }\end{array}$ & $\begin{array}{l}\text { "Information systems are the means by which organizations and } \\
\text { people, utilizing information technologies, gather, process, store, } \\
\text { and use and disseminate information." }\end{array}$ \\
\hline $\begin{array}{l}\text { Gray }(2006, \mathrm{p} \text {. } \\
305)\end{array}$ & $\begin{array}{l}\text { "An automated or manual collection of people, machines, and/or } \\
\text { methods to gather, process, transmit, and disseminate data. } \\
\text { Information systems are used to acquire, store, manipulate, manage, } \\
\text { display, transmit, or receive data. It includes both hardware and } \\
\text { software." }\end{array}$ \\
\hline $\begin{array}{l}\text { Huber et al }(2007, \\
\text { p. 392) }\end{array}$ & $\begin{array}{l}\text { "An organized collection of people, information, business } \\
\text { processes, and information technology designed to transform inputs }\end{array}$ \\
\hline
\end{tabular}




\begin{tabular}{|c|c|}
\hline & into outputs, in order to achieve a goal." \\
\hline $\begin{array}{l}\text { O'Brien (2003, p. } \\
\text { G-10) }\end{array}$ & $\begin{array}{l}\text { "(1) A set of people, procedures, and resources that collects, } \\
\text { transforms, and disseminates information in an organization. } \\
\text { (2) A system that accepts data resources as input and processes } \\
\text { them into information products as output." }\end{array}$ \\
\hline $\begin{array}{l}\text { Checkland \& } \\
\text { Holwell (1998, } \\
\text { pp. 110-111), } \\
\text { cited by } \\
\text { Magalhães (1999, } \\
\text { p. 6) }\end{array}$ & $\begin{array}{l}\text { "Any and every information system can always be thought of as } \\
\text { entailing a pair of systems, one a system which is served (the } \\
\text { people taking the action), the other a system that does the serving } \\
\text { [i.e., the processing of selected data (capta) relevant to people } \\
\text { undertaking purposeful action]." }\end{array}$ \\
\hline $\begin{array}{l}\text { Falkenberg et al } \\
(1998, \text { p. } 73)\end{array}$ & $\begin{array}{l}\text { "An information system is a sub-system of an organisational } \\
\text { system, comprising the conception of how the communication- and } \\
\text { information-oriented aspects of an organisation are composed (e.g. } \\
\text { of specific communicating, information-providing and/or } \\
\text { information-seeking actors, and of specific information-oriented } \\
\text { actands) and how these operate, thus describing the (explicit and/or } \\
\text { implicit) communication-oriented and information-providing } \\
\text { actions and arrangements existing within that organisation." }\end{array}$ \\
\hline $\begin{array}{l}\text { Kroenke (2008, p. } \\
6)\end{array}$ & $\begin{array}{l}\text { A group of components that interact to produce information. [The } \\
\text { five components of an information system are hardware, software, } \\
\text { data, procedures, and people.] }\end{array}$ \\
\hline $\begin{array}{l}\text { Laudon \& } \\
\text { Laudon }(2007, p \text {. } \\
\text { G-7) }\end{array}$ & $\begin{array}{l}\text { Interrelated components working together to collect, process, store, } \\
\text { and disseminate information to support decision making, } \\
\text { coordination, control, analysis, and visualization in an organization. }\end{array}$ \\
\hline $\begin{array}{l}\text { Rainer et al } \\
(2007, \text { p. 393) }\end{array}$ & $\begin{array}{l}\text { A process that collects, processes, stores, analyzes, and } \\
\text { disseminates information for a specific purpose; most ISs are } \\
\text { computerized. }\end{array}$ \\
\hline $\begin{array}{l}\text { Watson (2008, p. } \\
\text { 9) }\end{array}$ & $\begin{array}{l}\text { "An information system is an integrated and cooperating set of } \\
\text { software directed information technologies supporting individual, } \\
\text { group, organizational, or societal goals." }\end{array}$ \\
\hline $\begin{array}{l}\text { Jessup \& } \\
\text { Valacich }(2008, \\
\text { p. } 567)\end{array}$ & $\begin{array}{l}\text { "Assumed to mean computer-based systems, which are } \\
\text { combinations of hardware, software, and telecommunications } \\
\text { networks that people build and use to collect, create, and distribute } \\
\text { useful information." }\end{array}$ \\
\hline TechWeb 2008 & $\begin{array}{l}\text { "A business application of the computer. It is made up of the } \\
\text { database, application programs and manual and machine } \\
\text { procedures. It also encompasses the computer systems that do the } \\
\text { processing." }\end{array}$ \\
\hline $\begin{array}{l}\text { McLeod \& Schell } \\
(2007, \text { p. 19) }\end{array}$ & $\begin{array}{l}\text { "Information systems are virtual systems; their data represents the } \\
\text { physical system of the firm." }\end{array}$ \\
\hline $\begin{array}{l}\text { Wand \& Weber } \\
(1990, \text { pp. 62-63) }\end{array}$ & $\begin{array}{l}\text { "Information systems are primarily intended to model the states and } \\
\text { behavior of some existing or conceived real world system." ... "We } \\
\text { conceive of an information system as an object that can be studied } \\
\text { in its own right, independently of the way it is deployed in its } \\
\text { organizational and social context, and the technology used to }\end{array}$ \\
\hline
\end{tabular}




\begin{tabular}{|l|l|}
\hline & $\begin{array}{l}\text { implement it. In other words, when modeling an information } \\
\text { system we are not concerned with the way it is managed in } \\
\text { organizations, the characteristics of its users, the way it is } \\
\text { implemented, the way it is used, the impact it has on such factors as } \\
\text { quality of working life or the distribution of power in organizations } \\
\text { or the type of hardware or software used to make it operational." }\end{array}$ \\
\hline Pawlak (2002) & $\begin{array}{l}\text { "An information system is a data table, whose columns are labeled } \\
\text { by attributes, rows are labeled by objects of interest and entries of } \\
\text { the table are attribute values." }\end{array}$ \\
\hline $\begin{array}{l}\text { Tadeusz \& } \\
\text { Rybnik (1992, p. } \\
182)\end{array}$ & $\begin{array}{l}\text { "An information system is a pair A = (U, A), where U - is a } \\
\text { nonempty, finite set called the universe and A - is a nonempty, }\end{array}$ \\
\hline
\end{tabular}

Adding to the confusion is the fact that many systems that process information are integral parts of other systems that do things in addition to processing information. Remove the system that is being served and the information system becomes meaningless. Remove the information processing and the larger system grinds to a halt.

Much of the value of this paper's proposed definition, and of any other definition, derives from the concepts, frameworks, and types of analysis that are motivated by the definition. For example, in an article about the deep structure of information systems, Wand \& Weber (1990) implicitly define information systems as representations of real world systems: "Information systems are primarily intended to model the states and behavior of some existing or conceived real world system." ... "In other words, when modeling an information system we are not concerned with the way it is managed in organizations, the characteristics of its users, the way it is implemented, the way it is used, ..." Wand and Weber's clarity about their purpose led to a stream of important research related to conceptual modeling. (e.g., see Wand \& Weber (2002)). On the other hand, their approach does not take into account sociotechnical issues that many other researchers believe important.

This paper's definition of information system as a special case of work system (Alter, 1999a, 2003a) leads directly to a set of concepts, frameworks, and analysis methods that are relevant to the four types of objects that Carvalho (2000) identified. It also has implications in many areas of IS practice and research. The next sections explain the definition and evaluate it based on a slight modification of criteria proposed by Järvelin \& Wilson (2003) for evaluating conceptual models:

- Simplicity: Simpler definitions are better, other things being equal.

- Clarity: Good definitions contain concepts that are clear and explicit.

- Scope: Good definitions cover the scope of the area of interest and do not overlook important phenomena and issues.

- Systematic power: Good definitions help in organizing concepts, relationships and information related to whatever is being defined. 
- Explanatory power: Good definitions help in describing and explaining phenomena and predicting outcomes.

- Validity: Good definitions lead to valid representations and findings across the full range of relevant situations.

- Reliability: Good definitions lead to relatively similar observations and understandings when applied to the same situation by different observers.

- Fruitfulness: Good definitions lead to important questions for research and practice, and help in answering those questions.

A concluding section reviews advantages of the proposed definition and poses a challenge for other definitions. The Appendix summarizes previously published concepts, two frameworks, and a systems analysis method, all of which flow from the proposed definition and are useful for appreciating many points in this paper's evaluation section.

\section{Defining an Information System as a Work System}

The definition of an information system is based on the more general concept of work system. Businesses operate through work systems. Typical business organizations contain work systems that procure materials from suppliers, manufacture physical and/or informational products, deliver products to customers, find customers, create financial reports, hire employees, coordinate work across departments, submit tax payments, and perform many other functions.

A work system is a system in which human participants and/or machines perform work (processes and activities) using information, technology, and other resources to produce specific products and/or services for specific internal or external customers.

An information system is a work system whose processes and activities are devoted to processing information, i.e., capturing, transmitting, storing, retrieving, manipulating, and displaying information.

Thus, an information system is a system in which human participants and/or machines perform work (processes and activities) using information, technology, and other resources to produce informational products and/or services for internal or external customers.

Examples of information systems include work systems devoted to generating corporate plans, creating computer programs, generating financial statements, creating digital products such as software and electronic games, performing economic analysis, writing music, rebalancing stock portfolios, and determining prices of airline seats based on complex yield management calculations.

This definition covers all four types of objects identified by Carvalho (2000): 
IS1: Entire organizations that provide information for clients can be viewed as work systems. The frameworks and analysis methods described in the Appendix were developed based on the premise that most organizations contain multiple work systems. Consequently the frameworks and analysis methods are somewhat useful for viewing smaller organizations as single work systems and less useful for large organizations that contain multiple work systems that should be analyzed separately.

IS2: Information systems that assure communication between managerial and operational sub-systems of an organization can be viewed as work systems. Throughout the development of the work system approach, management and communication systems were viewed as typical work systems.

IS3: Pure computer systems can be viewed as work systems in which machines do all of the work. The intention to include totally automated systems within the work system approach is one of the reasons for using the term work system instead of Checkland's (1999) term human activity system.

IS4: Any combination of people and machines that deal only with symbolic objects (information) can be viewed as information system if that combination exists to produce specific products and services for specific customers.

IT-reliant work systems. The fact that a work system uses IT extensively does not imply that it is an information system. The following are examples of work systems that use IT extensively but are not information systems: fulfillment systems for physical goods, package delivery systems, highly automated manufacturing systems, medical systems that include physical examination or treatment of patients, and transportation systems that use IT extensively. In such cases, an information system may produce intermediate products and services that are meaningful and useful primarily in the context of a larger work system that involves activities beyond processing of information. Alternatively, the processing of information may be so intertwined with the work system that it is barely meaningful to speak of the information system as a separate system.

Increasing reliance on computerized information systems has led to increasing degrees of overlap between work systems and the information systems that support them. This trend implies that a clear IS definition should distinguish between information systems and ITreliant work systems (of which information systems are a special case whose processes and activities are devoted to information and that produce informational products and services). This distinction is often ignored because IT-reliant work systems are sometimes treated as subject matter within in the IS field, an inclusion that may have significant benefits for the IS field. (Alter, 2003a; 2003b)

Other categories of work systems. Information system is only one of a number of special cases of work system that are important in the information system field. 
- A project is a work system designed to go out of existence after producing specific products and services for customers. Each major project phase or subproject might also be viewed as a separate work system with its own processes and activities, participants, and products.

- A value chain can be viewed as a work system that crosses several functional areas of business and whose participants typically reside in different departments. Each major step in a value chain can be viewed as a subsystem that is also a work system.

- A supply chain is an interorganizational work system devoted to procuring materials and other inputs required to produce a firm's economic products and services. The firm and specific suppliers are participants in processes and activities that use specific information and technology to create, monitor, and fulfill orders.

- An ecommerce web site can be viewed as a self-service work system in which a customer uses the seller's web site in a process of matching requirements to product offerings and then making the purchase. By focusing attention on the customer's actions and desired outcome, a work system view helps in recognizing why an attractive interface does not assure a web site's success.

The fact that systems of any of these types can be viewed as work systems implies that the same basic concepts and analysis ideas apply for all of these cases. For example, it is possible to use work system elements (identified by the work system framework, Figure 2 in the Appendix) to summarize any work system, including any information system, project, supply chain, or ecommerce web site. Being able to start from the same big picture ideas and models makes it easier to think about a broad range of situations even though each special case may have its own specialized terminology for specific topics.

Previous use of "work system." Before proceeding, it is worthwhile to note that the term work system was used occasionally in a number of articles over the last thirty years, including two articles by Bostrom and Heinen (1977a, 1977b) in the first volume of MIS Quarterly. (See Table 2) It may not have been defined clearly and treated as an analytical concept until the third edition of an IS textbook (Alter, 1999b) and an article called "A General, but Useful Theory of Information Systems." (Alter, 1999a) The term high performance work system has appeared occasionally (without a definition of work system) in the popular business press and in some consulting circles to describe organizations with high degrees of participation and self-management. 
Table 2 Examples of previous uses of the term work system

\begin{tabular}{|l|l|}
\hline \multicolumn{1}{|c|}{ Authors } & \multicolumn{1}{c|}{ Representative statement } \\
\hline $\begin{array}{l}\text { Bestrom \& } \\
17 \text { and 18) }\end{array}$ & $\begin{array}{l}\text { The socio-technical systems approach "is used for redesigning existing } \\
\text { work systems as well as for new site designs." .. "When one intervenes in } \\
\text { a work system, two potential improvements are possible. The first is an } \\
\text { improvement in task accomplishment ... The second is an improvement in } \\
\text { the quality of working life." }\end{array}$ \\
\hline $\begin{array}{l}\text { Mumford \& } \\
\text { Weir (1979, p. 3) }\end{array}$ & $\begin{array}{l}\text { "The ETHICS method consists of a set of steps which must be taken in the } \\
\text { design and implementation of a new work system." }\end{array}$ \\
\hline $\begin{array}{l}\text { Davis and Taylor } \\
\text { (1979, p. xv) }\end{array}$ & $\begin{array}{l}\text { "Job design ... had its origins in attempts at comprehensive work systems } \\
\text { embedded." }\end{array}$ \\
\hline $\begin{array}{l}\text { Trist (1981, p. } \\
11)\end{array}$ & $\begin{array}{l}\text { "Primary work systems ... are the systems which carry out the set of } \\
\text { activities involved in an identifiable and bounded subsystem of a whole } \\
\text { organization - such as a line department or service unit." }\end{array}$ \\
\hline $\begin{array}{l}\text { Sumner \& Ryan, } \\
(1994)\end{array}$ & $\begin{array}{l}\text { "While social aspects are important in the design of work systems, these } \\
\text { aspects are not supported by CASE tools. ..Current CASE tools do not } \\
\text { fully support the process of generating multiple design alternatives for the } \\
\text { new work system." }\end{array}$ \\
\hline $\begin{array}{l}\text { Mitchell \& } \\
\text { Zmud (1999,p. p. } \\
425 \text { and p. 434) }\end{array}$ & $\begin{array}{l}\text { "When the viability of [a] new work system depends on IT, the process } \\
\text { innovation is IT-enabled. .. Usually substantial gaps between the } \\
\text { organization's IT infrastructure and the IT requirements of the adopted } \\
\text { work system would be recognized and dealt with before planners develop } \\
\text { and implement the new work system." }\end{array}$ \\
\hline $\begin{array}{l}\text { "Socio-technical methods focus on design of work systems to improve the } \\
\text { welfare of employees. The prime aim of redesigning work systems is the } \\
\text { improvement of the quality of working life." }\end{array}$ \\
\hline
\end{tabular}

In contrast to the relatively informal use of the term work system in the examples in Table 2, a careful definition that overlaps with our proposed definition but defines a work system as a context (rather than a system) appears in Jasperson et al (2005):

"The work system represents the context within which organizational members perform their assigned work. Thus, the work system includes organizational members, the work tasks undertaken by members, work processes, technology features that enable or support work tasks and processes, and social structures that direct organizational members both in their work-related behaviors and in their interactions with each other. ... An organization's members are obviously core elements of the work system, both in performing work-related roles and as users of work-enabling technologies. Most important, given that an organization's members continuously interpret their work context their work system sensemaking becomes an especially critical subcomponent of the work system." (p. 535)" 
The value of defining information system as a special case of work system is based on the applicability of ideas and analysis methods related to work systems. The Appendix summarizes a set of concepts, two frameworks, and an analysis method related to work systems. Various parts of that material were published in various evolving versions over the last decade. Even readers familiar with the work system framework and work system life cycle model might want to glance at the Appendix because the rest of the paper assumes familiarity with its contents.

\section{Evaluating the Proposed Definition}

This section evaluates the proposed definition of IS based on each of the criteria mentioned at the outset.

\section{Simplicity}

The proposed two-part definition is relatively simple and understandable.

- An information system is a work system whose processes and activities are devoted to processing information, i.e., capturing, transmitting, storing, retrieving, manipulating, and displaying information.

- A work system is a system in which human participants and/or machines perform work (processes and activities) using information, technology, and other resources to produce specific products and/or services for specific internal or external customers.

Alter (2007b) discusses how work system ideas have been applied in over 200 (more recently over 300) student papers. Students analyzing specific situations are reasonably able to identify human participants, information, technology, products and services, and customers. They also understand the meaning of the six types of information processing activities and recognize examples of information technologies to perform each type of activity. For example, in a classroom environment Petkov \& Petkova (2006) found the work system framework useful to undergraduate students trying to understand an ERP implementation situation.

Straightforward but not simplistic. Note the term "reasonably able" in the paragraph above. Although the work system framework is reasonably easy understand as an abstraction, it is sometimes challenging to apply in situations in which the scope of the system is not known in advance. That condition occurs in most real-world analyses of sociotechnical systems. Alter (2007b) notes that the most experienced student teams tend to report longer and more contentious debates about the identity and boundaries of the system they should analyze to produce recommendations related to a real world problem or opportunity. The less experienced student teams sometimes seem not to realize why this is an important issue. In both instances, as the student teams progress with the 
analysis they sometimes find that their original definition of the system is inadequate. In some cases they even redefine the problem they are trying to solve.

Challenges in applying the proposed definition are probably no greater than challenges in applying any other sociotechnical definition of information system in real world situations because the boundary and scope of the system is usually in question. In contrast, computer-oriented definitions can be simpler in cases where the computer system and/or software of interest are highly localized and defined in advance.

\section{Clarity}

Good definitions contain concepts that are clear and explicit. The proposed definition of IS and the frameworks that follow from it are clear enough to express and underscore important distinctions in the IS field.

Differentiation between IS and IT. Many authors have expressed concerns about the common blurring of IS and IT, which is clarified by defining IS as a special case of work system. Technology and infrastructure are elements of the work system framework. The definition implies that a computer is not an information system because a computer does not produce specific products and services for specific customers. Similarly, word processing programs and suites of software such as ERP products are not information systems. Rather, depending on the purpose of the analysis, they should be treated either as part of the technology within a specific information system or as part of the technical infrastructure shared among multiple information systems.

Treatment of IS as a system, rather than a tool. The IS discipline is ostensibly about systems, but many of its fundamental ideas and viewpoints are about tools, not systems. (Alter, 2004) For example, our basic vocabulary implies that IT vendors and IT groups provide tools and that an IT group's "users" use them. Similarly, typical concepts about IS success imply that a tool's success is measured by whether it fits specifications, how well it is used, and what is its impact. Likewise, system development often refers to developing software tools that meet requirements and satisfy perceived needs of users, rather than developing or modifying a work system in an organization.

Table 3 compares "tool view" of IS with a "system view" of IS. With a tool view, the headline is the tool that is being used. In contrast, a system view focuses on a system of doing something. With a tool view, the people are users of the tool, whereas a system view of a system in an organization treats people as participants in the system. 
Table 3 Comparing a "tool view" of IS with a "system view" of IS (Alter, 2004)

\begin{tabular}{|c|c|c|}
\hline $\begin{array}{l}\text { Area of } \\
\text { comparison }\end{array}$ & Tool View & System View \\
\hline Headline & The tool that is used & The system of doing something \\
\hline $\begin{array}{l}\text { Role of } \\
\text { people }\end{array}$ & Users of the tool & Participants in the system \\
\hline Information & $\begin{array}{l}\text { Whatever information is stored } \\
\text { or processed by the tool }\end{array}$ & $\begin{array}{l}\text { Whatever codified or non-codified } \\
\text { information is produced or used by the } \\
\text { system }\end{array}$ \\
\hline Technology & $\begin{array}{l}\text { The tool is the technology or is a } \\
\text { part of the technology }\end{array}$ & $\begin{array}{l}\text { The system may use a variety of } \\
\text { technologies that may or may not } \\
\text { involve IT. }\end{array}$ \\
\hline Customers & $\begin{array}{l}\text { Users of the tool or whatever the } \\
\text { tool produces }\end{array}$ & $\begin{array}{l}\text { People who receive and use whatever } \\
\text { the system produces. }\end{array}$ \\
\hline $\begin{array}{l}\text { Performance } \\
\text { variables } \\
\text { related to } \\
\text { operation }\end{array}$ & $\begin{array}{l}\text { Measure how well the tool } \\
\text { operates and how well it is used. } \\
\text { Typical metrics include user } \\
\text { satisfaction, uptime, energy } \\
\text { usage, ease of use, and degree of } \\
\text { use, }\end{array}$ & $\begin{array}{l}\text { Measure how well the system operates } \\
\text { internally and how good are the } \\
\text { products and services it produces. } \\
\text { Typical metrics nclude speed, } \\
\text { consistency, rate of output, rate of } \\
\text { rework, reliability, quality, and total } \\
\text { cost to the customer. }\end{array}$ \\
\hline $\begin{array}{l}\text { Life cycle } \\
\text { model }\end{array}$ & $\begin{array}{l}\text { A project-oriented model related } \\
\text { to defining, creating or } \\
\text { acquiring, and installing the tool }\end{array}$ & $\begin{array}{l}\text { Model of long-term change in a } \\
\text { sociotechnical system that evolves } \\
\text { through a series of iterations of system } \\
\text { in operation, initiation of changes, } \\
\text { development efforts, and } \\
\text { implementation of changes in the } \\
\text { organization. The iterations often } \\
\text { encompass planned and unplanned } \\
\text { change. }\end{array}$ \\
\hline Ownership & $\begin{array}{l}\text { A tool may be owned by the } \\
\text { organization that uses it or by an } \\
\text { organization that controls tools } \\
\text { or provides shared infrastructure. }\end{array}$ & $\begin{array}{l}\text { A system is owned by the organization } \\
\text { a part of whose work it performs. }\end{array}$ \\
\hline $\begin{array}{l}\text { Performance } \\
\text { variables } \\
\text { related to } \\
\text { change }\end{array}$ & $\begin{array}{l}\text { In a new setting, measure the } \\
\text { tool's diffusion and acceptance. } \\
\text { In a setting where the tool is } \\
\text { already used, measure the tool's } \\
\text { usefulness, success, and cost/ } \\
\text { effectiveness. }\end{array}$ & $\begin{array}{l}\text { For a new system that is being created, } \\
\text { measure the implementation effort and } \\
\text { extent to which the system is } \\
\text { institutionalized in its originally } \\
\text { desired form. For an existing system, } \\
\text { measure the effort involved in } \\
\text { defining, implementing, and } \\
\text { stabilizing a change }\end{array}$ \\
\hline $\begin{array}{l}\text { Main issues } \\
\text { in analysis } \\
\text { and design }\end{array}$ & $\begin{array}{l}\text { Produce a tool that meets } \\
\text { requirements in a cost effective } \\
\text { manner, is installed successfully, }\end{array}$ & $\begin{array}{l}\text { Create or improve a sociotechnical } \\
\text { system, assuming that technical and } \\
\text { social issues may be intertwined and }\end{array}$ \\
\hline
\end{tabular}


Recognition of the sociotechnical nature of IS. The proposed definition of IS is a sociotechnical definition because it includes people both as system participants and as internal or external customers of the system. With both participants and customers clearly in view, the description or analysis of a system tends to include topics such as the skills, interests, incentives, and social relations of the people in the system. In contrast, IS definitions that focus on hardware and software do little to focus attention on sociotechnical issues and concerns.

Although clearly in the sociotechnical camp, the proposed definition does not try to establish a separation between a technical system and social system as is discussed by many proponents of sociotechnical approaches (e.g., Mumford \& Weir, 1979;

Hirschheim \& Klein, 1994). Simplicity is the main reason for taking the more integrated view expressed in the work system framework, whose nine elements provide useful headings for summarizing the different parts of a work system. Trying to separate the social system from the technical system is more difficult. For example, in many cases specific activities and business process steps can be viewed simultaneously as part of the social system and the technical system. In such cases, it is unlikely that most business people, IT professionals, and non-Ph.D. analysts would be willing or able to make that type of distinction.

Inclusion of highly automated information systems. While recognizing the sociotechnical nature of IS, the proposed definition also covers highly automated information systems because it says that human participants and/or machines perform work (processes and activities) using information, technology, and other resources.

Examples such as online search and e-commerce illustrate how participants fit into a work system view of a highly automated information system. In the case of online search, someone wanting to retrieve information needs to formulate the query and needs to evaluate the response from the search engine. Even a relatively minimal view of online search involves a least five steps: the framing of the issue by the participant, the formulation and entry of the query by the participant, the automated search for the relevant links, the display of search results to the participant, and the participant's evaluation of whether to accept the result or perform another query. The person in this situation might be viewed as a user of a tool or as a participant in an information system. Viewing the situation as an information system with a human participant rather than a tool with a human user leads to a richer analysis because the scope starts with formulation of needs and ends with evaluation of the search engine's response. The tool/ user view focuses on the form, affordances, and limitations of the interface. The system view includes those factors, but goes much further in showing why the limiting factor is sometimes the person rather than the technology.

A more extreme example is a computerized facility monitoring system that is set up and then operates autonomously for months or years. That type of situation is basically a 
boundary case because the participant slot becomes less and less interesting unless the analysis focuses on how the system is initialized and/or on how people respond to the detection of exception conditions. Also, people tend not to be totally absent from information systems whose main activities and processes are totally automated. In such cases they are part of the human infrastructure that keeps the information system operating.

Avoidance of confusions with IT artifacts. Thinking of IS as a type of work system bypasses the unfortunate confusion related to the term "IT artifact." Alter (2003b) This term was popularized by Orlikowski and Iacono's (2001) widely cited article that discussed five different ways of treating the IT artifact in IS research. Unfortunately, the term artifact has a number of meanings such as an object produced or shaped by human craft, something viewed as a product of human conception or agency, or an inaccurate observation, effect, or result or an error. (e.g., see www.dictionary.com) To many people in the IS field, the term IT artifact strongly suggests computerized objects that are produced and have readily discernible form and boundaries, such as a computer program, cellphone, or iPod. In contrast, Orlikowski \& Iacono's definition of IT artifact, "bundles of material and cultural properties packaged in some socially recognizable form such as hardware and/or software," leads some people to say that anything that IT affects in a significant way is an IT artifact. The result is a significant lack of clarity, as illustrated by gaps between three definitions of IT artifact in Table 4. For example, what guidance would these three definitions provide in discerning the boundary between situations that are affected enough by IT that they should be called IT artifacts and other situations that should not be called IT artifacts even though IT happens to be present? If something that uses IT can be called an IT artifact, why shouldn't something that uses electricity be called an electricity artifact? The clarity of the proposed IS definition sidesteps these terminological confusions.

Table 4 What is an IT artifact?

\begin{tabular}{|l|l|}
\hline \multicolumn{1}{|c|}{ Term } & \multicolumn{1}{c|}{ Definition } \\
\hline Iacono, 2001) & $\begin{array}{l}\text { "By and large, IT artifacts (those bundles of material and cultural } \\
\text { properties packaged in some socially recognizable form such as } \\
\text { hardware and/or software) continue to be under theorized." (p. } \\
\text { 121) }\end{array}$ \\
& $\begin{array}{l}\text { Five premises for theorizing about IT artifacts (p. 131) include: } \\
\text { 1. "IT artifacts, by definition, are not natural, neutral, universal, or } \\
\text { given." } \\
\text { 2.'IT artifacts are always embedded in some time, place, } \\
\text { discourse, and community." } \\
\text { 3. "IT artifacts are usually made up of a multiplicity of often } \\
\text { fragile and complementary components, whose interconnection } \\
\text { are often partial and provisional and which require bridging, } \\
\text { integration, and articulation in order for them to work together." } \\
\text { 4. "IT artifacts are neither fixed nor independent, but they emerge }\end{array}$ \\
\hline
\end{tabular}




\begin{tabular}{|l|l|}
\hline & $\begin{array}{l}\text { from ongoing social and economic practices." } \\
\text { 5. "IT artifacts are not static or unchanging, but dynamic." }\end{array}$ \\
\hline $\begin{array}{l}\text { (Benbasat \& Zmud, } \\
\text { "We3) }\end{array}$ & $\begin{array}{l}\text { "We conceptualize the IT artifact as the application of IT to } \\
\text { that itself is embedded within a context(s)." (p. 186). The four } \\
\text { elements of an IT artifact include information technology, task, } \\
\text { task structure, and task context (Figure 1, p. 188) }\end{array}$ \\
\hline $\begin{array}{l}\text { (Agarwal \& Lucas, } \\
\text { 2005) }\end{array}$ & $\begin{array}{l}\text { "We also recommend expanding the definition of the IT artifact } \\
\text { from "enabling or supporting some tasks" to specify IT as the } \\
\text { integration of the processing logic found in computers with the } \\
\text { massive stores of databases and the connectivity of } \\
\text { communications networks. The IT artifact includes IT } \\
\text { infrastructure, innovations with technology, and especially the } \\
\text { Internet." (p. 394) }\end{array}$ \\
\hline
\end{tabular}

\section{Scope}

Good definitions cover the scope of the area of interest and do not overlook important phenomena and issues. Aside from clarifying what is and is not an information system, the proposed definition is broadly inclusive and can be associated directly with most of the subject matter of the IS field. In contrast, some of the other definitions of IS are basically about computer systems, traditional organizational control systems, or organizations in general. Such definitions do little to include various types of information systems that may not have been important in the past but are important today.

Scope of the IS field. The distinction between information systems and IT-reliant work systems leads to a question about the scope of the information system field. Alter (2003b) argues that the core of today's information systems discipline is IT-reliant work systems, which include both pure information systems and IT-reliant work systems that produce both physical and informational products. The broader view including IT-reliant work systems is necessary because the narrower view including only pure information systems would place many important phenomena concerning business processes, organizational change, and competitive uses of IT outside the boundaries of the IS field. Consistent with observations by Ackoff (1993) and Checkland (1999) concerning the necessity of understanding the system that is being served whenever analyzing a system, important aspects of IS research look beyond the operation of information systems per se. Viewing the IS field as the study of IT-reliant work systems, rather than just information systems per se leads to better approaches for developing models of IS success, understanding IS costs, understanding the productivity paradox, understanding IS related risks, communicating with business professionals, and penetrating techno-hype and technocentrism. For other reasons see Alter (2003a).

Inclusion of a range of situations. Although a very detailed look at the nine elements of the work system framework is beyond this paper's scope, even a brief look at the elements illustrates the wide range of situations covered by the definition of IS. 
Customers may include both internal and external customers who may be viewed as recipients of whatever the IS produces or as co-producers of value in selfservice situations.

Products and services may be produced by an information system, and different groups of customers may benefit from offerings of different products and services.

Processes and activities cover much more than totally structured processes that appear in some IS definitions as "procedures." As happens in collaboration systems and many other situations, various processes and activities performed by participants may be structured, semi-structured, or unstructured.

Participants include both IT users and non-users, thereby emphasizing that the relevant participants are people who do some of the work, not just people who use IT.

Information includes codified and non-codified information used and created as participants perform their work.

Technologies include IT and other tools that should not be categorized as IT even if they contain embedded IT applications.

Infrastructure includes relevant human, information, and technical resources that are managed outside of the work system (or information system) and are shared with other work systems.

Environment includes the relevant organizational, cultural, competitive, technical, and regulatory environment within which the work system operates, thereby recognizing that an information system's success depends partly on surrounding factors that are not part of the information system.

Strategies of the work system and/or organization help in understanding any work system but may or may not be articulated.

\section{Systematic Power}

Good definitions help in organizing concepts, relationships and information related to whatever is being defined. Defining information system as a work system devoted to processing information implies that most or all of the concepts and knowledge that apply to work systems in general also apply to information systems. For example, many concepts and much knowledge exist related to processes, information, and people at work. That same knowledge is equally applicable to work systems in general and to information systems. In turn, any additional concepts and knowledge that are relevant to information systems should be relevant to special cases of information systems, such as transaction 
processing systems, decision support systems, or computer aided design systems. Inheritance of concepts from work systems in general to information systems in general and then to special cases of information systems has a number of implications for the information system field

Body of knowledge for the IS field. The challenge of defining the domain and core concepts of the IS field is a perennial topic at major IS conferences. (e.g., see Hirschheim and Klein, 2003) Many of the frustrations with the current IS field reflect its existence as a loose, unsettled conglomeration of partly overlapping slices of terminology and knowledge related to a wide range of fields such as conceptual modeling, organization behavior, total quality management, human communication, coordination theory, information theory, computer science, and microeconomics.

An offshoot of the attempt to develop the work system approach was an attempt to develop Sysperanto (Alter, 2005), a model-based ontology of the IS field. The architecture of Sysperanto is organized around the work system framework and the inheritance of concepts (properties) from more general types of work systems to less general types. Since information systems, projects, supply chains are all special cases of work systems, each of those special cases should inherit concepts and knowledge that exists for work systems in general. Work system types are summarized in terms of the nine elements included in the work system framework. Each of those elements is understood through a series of "slices." For example, decision making, communicating, and coordinating are three of the slices that are often useful when analyzing processes and activities within a specific work system. Each of the slices provides a vocabulary of concepts related to work systems or their elements. The concepts themselves may refer to components, actions or functions, characteristics, performance variables, relationships, phenomena, and generalizations.

An attempt to flesh out the concepts at the work system level is not yet complete. The next step in developing Sysperanto will attempt to determine the extent to which those concepts are truly inherited by information systems and projects, and also the extent to which the special cases have their own unique concepts. The underlying hope, definitely not proved at this point, is that most of the important concepts at each level below "work system in general" will be inherited from a higher level. Figure 1 illustrates these inheritance relationships using the example of success factors. A related paper (Sherer and Alter, 2004) noted that over half of the risk factors in a convenience sample of 46 papers related to IS risk were actually risk factors related to work systems in general, rather than IS in general, particular types of IS, or IS projects. 


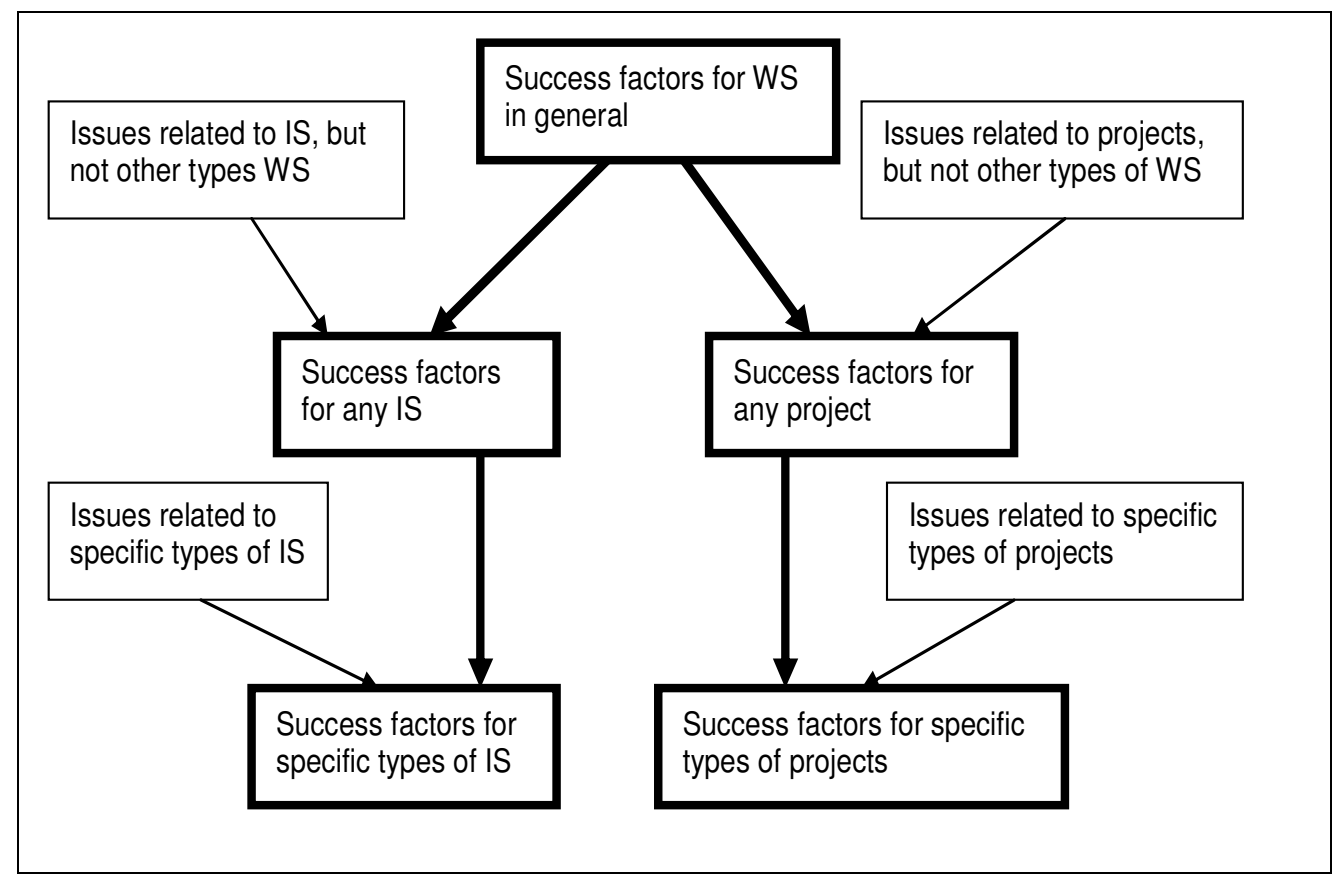

Figure 1 Inheritance of success factors from work systems in general to special cases

\section{Explanatory Power}

Ideally, the definition and its implications should enhance our ability to explain and predict phenomena. This section demonstrates that the proposed IS definition and the and the related ideas lead to insights in interpreting past research, understanding the relationship between IT spending and business results, identifying and overcoming common confusions, explaining why IT matters, and explaining the incoherence of the IS field.

Very general questions for understanding empirical research. Based on the definition of IS, even a rudimentary understanding of the information system (or information systems) being studied by an empirical research study requires knowledge of the customers, products and services, processes and activities, participants, information, and technologies. When reading an empirical research article, an obvious question to ask is whether the article was clear about these six elements and how they shaped the information system or sample of systems. Relatively obvious questions for interpreting the design, the sample, and the results include:

Customers: Did the information system have any customers? If so, were the customers satisfied with what information system produced?

Products and services: What did the information system(s) produce? 
Processes and activities: Were the processes and activities structured, semi structured or unstructured; simple or complex; tightly coupled or loosely coupled; frequent or infrequent; relatively controlled or relatively uncontrolled? And so on for other big picture characteristics.

Participants: What are the skills, interests, incentives, and social concerns of the participants? To what extent was the use of information technology genuinely important to the participants in doing their work and being successful?

Information: What codified and uncodified information was important in the situation and how did its quality and other characteristics affect the outcome?

Technologies: What technologies were important in this situation, and which characteristics and affordances of those technologies affected the results?

These questions are often revealing. As noted by Orlikowski \& Iacono (2001) using the terminology of IT artifacts, a substantial amount of research in the IS field does not refer to specific information systems and their reliance on IT. Rather, a specific capability may be tested, such as a computer users' ability to discern certain information. Alternatively, the research might look at something like the diffusion of a particular technology without reference to how it is actually used. Where there is an information system, it may not be clear that the information system is actually producing something for customers. In other cases, the research report may be unclear about whether the information system supports structured or unstructured business processes and activities. It may say little or nothing about the skills, interests, or incentives of the information system participants. Also, it may say little or nothing about uncodified information that was important in the situation(s) studied.

Recognizing missing links in IT success stories. Especially at a time when the IS field is sensitive about the competitive importance of IT, it is important to be able to identify the missing links in IT success stories. Obviously, every story stresses some things and deemphasizes others in order attain its own goals and maintain coherence. However, a knowledgeable interpretation of an IT success story should not ignore what is left out. The questions mentioned above for interpreting empirical research are equally useful for understanding IT success stories and identifying the missing links.

Understanding IS jargon. Discussions of systems and the IS field as a whole are rife with confusion because words such as system, information system, user, and implementation are used by different people to denote different things. Work system ideas are often useful in interpreting jargon related to information systems. The key is to remember that an information system is a special type of work system and to ask a simple question whenever jargon terms such as DSS, CRM, ERP, and BI are used:

Is an information system being discussed, and if so, what are its elements (i.e. customers, products and services, processes and activities, participants, information, technologies)? 
Sometimes it will turn out that an information system is being discussed, such as a particular way in which management information is provided and used for decision making in a particular setting. In other cases, the topic will be a type of software that is being touted, sold, or installed. For example, a software vendor selling what it calls a CRM (customer relationship management) system actually is selling software and possibly value added services. Viewing CRM software as "the system" is problematic if it leads one to forget that software is installed as part of an information system in which business professionals perform work that happens to use CRM software.

The unusually high failure rate of CRM has been attributed to many factors, including the immaturity of CRM software, difficulty in integrating CRM software with other software the organization, and confusion about what CRM is supposed to do. A work system perspective explains part of the problem. The business goal in using CRM software is creating better information systems for selling to customers, entering orders, providing customer service, and performing other customer-facing work. Starting from the premise that those are the goals, rather than implementing CRM software, might avoid some of the confusion that sometimes occurs when companies launched CRM initiatives. (e.g., see Schrage (2005))

ERP is another example of jargon with multiple meanings. Based on the definition of information system, commercially purchased ERP (enterprise resource planning) software is not an information system. Rather, it is technical infrastructure that is shared among multiple work systems, some or all of which may be information systems. ERP software and its impacts certainly fall within the scope of the information system field, however. In this case, having a clear definition of information system makes it easier to understand the true role of ERP software and the necessity of configuring various modules in a way that reflects reasonable trade-offs between possibly inconsistent requirements of many different information systems for various business functions.

Interpreting IS-related theories and ideas. The proposed definition of IS useful in interpreting a number of IS-related theories and ideas. As an example, consider the Delone and McLean IS Success Model.

"SYSTEM QUALITY and INFORMATION QUALITY singularly and jointly affect both USE and USER SATISFACTION. Additionally, the amount of USE can affect the degree of USER SATISFACTION - positively or negatively - as well as the reverse being true. USE and USER SATISFACTION are direct antecedents of INDIVIDUAL IMPACT; and lastly, this IMPACT on individual performance should eventually have some ORGANIZATIONAL IMPACT." (DeLone \& McLean, 1992).

As noted by DeLone \& McLean (2003) in an article that updated the original model in several ways, "nearly 300 articles in refereed journals have referred to, and made use of, the IS Success Model." 
Use of the definition of information system reveals that most of the concepts in the IS success model (system, system quality, use, user satisfaction, individual impact, and organizational impact) are problematic because the model does not recognize the distinction between software, an information system (defined as human participants and/or machines performing work ...) and the work system that the information system serves. It is not clear whether the user of the system is using its hardware and software to enter information or, alternatively, using information it produces. If either qualifies as IS use, then it is possible for data entry users to be satisfied and information users to be dissatisfied, and vice versa. In many real world situations it is not obvious which system (the information system or the work system that is served) exhibits "system quality" and "information quality," and which exhibits "success." Likewise, many of the individual and organizational impacts and satisfactions or dissatisfactions may be more directly related to the work system and its environment rather than to the information system.

It would be interesting to look at a variety of theories in the IS field to see whether the definition of IS provides insights about the theory and whether the theory provides insights about information systems. (The web site of the Association for Information Systems contains a page called "Theories in IS Research" that summarizes over 50 theories that are used in IS research.) In cases such as the theory of planned behavior, the theory is stated in terms of concepts that are relevant in most information systems (behavioral intentions, subjective norms, behavior) and probably describes the way most information system participants do their work. In other cases, such as the technology acceptance model (TAM), the theory leads to different concerns in different situations. For example, the application and validity of TAM depends on whether the information system involves mandatory use of the technology (e.g., an airline's reservation call center), voluntary use of the technology (e.g., use of spreadsheet software by an individual), or trial use and experimentation related to a technology that might be used in an operational information system but has not yet been adopted. In yet other cases, it is not obvious how the definition of information system helps in understanding the theory or vice versa.

Understanding why IT matters. A 2003 Harvard Business Review article with the inflammatory title "IT Doesn't Matter" (Carr, 2003) caused great consternation among IS professionals and academics because it challenged the value of most IT investments. Carr's argument was that IT doesn't matter because it is a commodity that anyone can purchase. Therefore firms should minimize their spending on IT.

The definition of information system leads to a quick and simple response that IT matters because it allows information systems and the work systems they support to operate in ways that otherwise would have been difficult or impossible. By the definition of system, skimping on the technology within a system will have impacts on the system's performance unless the capabilities of the technology truly are not relevant to system participants performing processes and activities to produce products and services for customers. The only time when skimping on technology will have no impact on an information system's performance is when the existing system is designed with unused technical capabilities. 
Understanding the competitive impacts of IT. The definition of IS helps in understanding the competitive impacts of IT because IT investments affect productivity and other results only when those investments are incorporated into information systems and the work systems they support. This leaves a question of how to define IT investment, i.e., whether IT investment involves anything other than the purchase and technical installation of computers, software, and networks.

Past research related to whether IT investments lead to greater productivity and profitability is directly relevant. Brynjolffson (2003) and others concluded that IT investments are positively correlated with business results, but that "IT is only the tip of a much larger iceberg of complementary investments that are the real drivers of productivity growth. ... For every dollar of IT hardware capital that a company owns, there are up to $\$ 9$ of IT-related intangible assets, such as human capital - the capitalized value of training - and organizational capital - the capitalized value of investments in new business-process and other organizational practices." These business process and organizational practices are information systems and the IT-reliant work systems they support. Most of the investment is in information systems and work systems rather than in IT per se. Consequently, the competitive impacts occur only when those additional investments occur.

Explaining the incoherence of the IS field. A conjecture in the 2005 Sysperanto paper mentioned earlier (Alter, 2005) may explain some of the difficulties underlying the "identity crisis" (Benbasat \& Zmud, 2003) of the IS discipline. Information systems as a category include transaction processing systems, MIS, DSS, CAD systems, e-commerce web sites, expert systems, group support system, communication systems, and many other types of IS. Worth considering, but not fundamental to the structure of Sysperanto, is the conjecture that the various types of information systems differ so greatly in form and function that information systems in general have few concepts or generalizations in common beyond those inherited from work systems in general.

According to this "level-skipping conjecture," most of the concepts and generalizations related to information systems in general are inherited from work systems in general; very few additional concepts and generalizations are related to information systems in general but not work systems in general; most of the additional concepts and generalizations related to information systems are related to unique features of specific types of information system.

This conjecture might help explain why it is so difficult to generalize about information systems and why the IS field seems to lack a conceptual core. It may turn out that almost all of the useful concepts and generalizations about information systems are either about work systems in general or about the various special cases of information systems. The conjecture would be shown invalid if one could identify a substantial set of valuable concepts and generalizations that apply to all of the information system types mentioned above but do not apply to work systems in general. 


\section{Reliability and Validity}

Good definitions should lead to valid representations and findings across the full range of relevant situations. They should also lead to relatively similar observations and understandings when applied to the same situation by different observers.

Although work system ideas have been applied in over 300 student papers, the reliability and validity of the proposed IS definition and other IS definitions have not been tested formally, at least to the author's knowledge. The concepts and frameworks in the work system approach were developed iteratively starting around 1996. At each stage, the then current version was tested informally by evaluating the areas of success and the difficulties experienced by MBA and Executive MBA students trying to use it for a practical purpose. After each semester, the papers were re-examined for implications about how the then current version of the work system approach might be improved.

Classroom experience and personal testimonials to date suggest that the work system framework and work system life cycle model are useful to MBA and Executive MBA students, both in class work and in their own professional work. Field-testing of the usefulness the IS definition and related frameworks would require experiments or pilot studies. After training, users would be compared to non-users trying to perform similar tasks related to recognizing, understanding, analyzing, and/or designing information systems. That research remains to be done.

\section{Fruitfulness}

Good definitions lead to important questions for research and practice, and help in answering those questions. In addition to motivating the author's research in developing the work system approach, the proposed definition has been applied by a number of researchers who used work system ideas. Ramiller (2002) reports used a version of the work system framework within a method for "animating" the idea of business process within an undergraduate class. Siau et al (2004) used the work system framework to analyze the value of mobile commerce to customers. Petrie (2004) used the work system framework in a Ph.D. thesis examining 13 ecommerce web sites. Petkov and Petkova (2006) demonstrated the usefulness of the work system framework by comparing results from students who did and did not learn about the framework before trying to interpret the same ERP case study. Ralph \& Wand (2007) used the work system framework as an underpinning of a proposed ontology of design concepts.

The proposed IS definition leads toward possible insights and developments in many areas including IS-related innovation, analysis and design from a sociotechnical perspective, communication between business and IT professionals, systems analysis for business professionals, better customer focus, and elevated centrality of service and service metaphors. 
Understanding of IS-related innovation. Understanding IS-related innovation from a work system viewpoint is consistent with the previously mentioned observation by Brynjolfsson (2003) that $\$ 9$ is spent on intangible assets such as processes, training, and organizational capital for each $\$ 1$ of IT hardware capital. Seeing IS-related innovation using the work system framework leads to a number of different starting points for thinking about IS-related innovations:

- Customers: Meet different needs of existing customers; Satisfy needs of new customers.

- Products and services: Improve the products and services produced by the information system

- Processes and activities: Change big picture characteristics of processes and activities such as degree of structure, level of integration, complexity, rhythm, treatment of exceptions, and so on. Alternatively, change the details by adding, removing, or combining steps or by changing the way specific steps are performed.

- Participants: provide new skills; change incentives; change social relations.

- Information: use different information or provide information in a different form or level of detail.

- Technologies: re-configure, upgrade, or replace technologies.

The assumption that IS innovation need not start with IT and might not involve IT changes might seem unusual, or possibly self-contradictory, but this broader view could motivate deeper understandings of important phenomena. Consider the disappointing adoption CASE (computer aided software engineering) technology. It once seemed that CASE would revolutionize system development in IT groups, but the extent of adoption has been disappointing, as demonstrated by a lengthy "assimilation gap" between acquisition of CASE and use for $25 \%$ of new applications. (Fichman \& Kemerer, 1999) Based on data through 1993, after 54 months only $24 \%$ of CASE acquisitions in their survey had resulted in that level of use. Around the same time, Orlikowski (1993) compared two CASE implementations and concluded that "the adoption and use of CASE tools should be conceptualized as a form of organizational change and that such a perspective allows us to anticipate, explain, and evaluate different experiences and consequences following the introduction of CASE tools in organizations." Noting that "even with its many benefits, most organizations have found it difficult to implement CASE," Sumner \& Ryan (1994) concluded that CASE tools support technical analysis of "the processes and data which are needed for correct task accomplishment by the work system," but that "social analysis is not well-supported by existing CASE tools." Looking at the work within the IS organization, they concluded, "for CASE to be effective, an organization may need to view information systems development as a work system."

Recognition that IS should be analyzed and designed as sociotechnical systems. The work system method treats work systems, including information systems, as sociotechnical systems. Important topics in the analysis include the skills, knowledge, interests, and social relations of the participants and various aspects of the environment, including the surrounding organization's culture, structure, and policies and procedures. 
In contrast, typical systems analysis textbooks used by information system students usually mention sociotechnical concerns in passing but focus primarily on the creation of technical artifacts rather than the improvement of sociotechnical systems. Table 5 demonstrates that pattern using brief excerpts from three systems analysis textbooks. Consistent with an emphasis on building technical artifacts, most systems analysis and design textbooks treat systems analysis and design as the special domain of IT professionals. With some exceptions such as Mathiassen et al (2000), most systems analysis and design textbooks ignore or barely mention soft systems methodology (Checkland, 1999) and other techniques that emphasize the social or sociotechnical nature of systems in organizations.

Table 5 Textbook views of analysis and design for information systems

\begin{tabular}{|c|c|}
\hline Textbook & $\begin{array}{l}\text { Brief excerpt from description of systems analysis and design as } \\
\text { phases of the system development life cycle (SDLC) }\end{array}$ \\
\hline \multirow[t]{2}{*}{$\begin{array}{l}\text { Dennis et al } \\
(2002)\end{array}$} & $\begin{array}{l}\text { Analysis Phase: "The analysis phase answers the questions of who } \\
\text { will use the system, what the system will do, and where and when it } \\
\text { will be used." [p. 5] }\end{array}$ \\
\hline & $\begin{array}{l}\text { Design Phase: "The design phase decides how the system will } \\
\text { operate, in terms of the hardware, software, and network } \\
\text { infrastructure; the user interface, forms, and reports, and the specific } \\
\text { programs, databases, and files that will be needed." [p. 6] }\end{array}$ \\
\hline \multirow[t]{2}{*}{$\begin{array}{l}\text { Hoffer et al } \\
(2002)\end{array}$} & $\begin{array}{l}\text { Analysis Phase: "In [the requirements definition subphase] ... } \\
\text { analysts work with users to determine what users want from the } \\
\text { proposed system ... The output of the analysis phase is a description } \\
\text { of (but not a detailed design for) the alternative solution } \\
\text { recommended by the analysis team. Once the recommendation is } \\
\text { accepted ... you can begin to make plans to acquire any hardware } \\
\text { and system software needed to build or operate the system as } \\
\text { proposed." [p. 21] }\end{array}$ \\
\hline & $\begin{array}{l}\text { Design Phase: "You must design all aspects of the system from } \\
\text { input and output screens to reports, databases, and computer } \\
\text { processes. You must then provide the physical specifics of the } \\
\text { system you have designed..." [p. 21] }\end{array}$ \\
\hline $\begin{array}{l}\text { Kendall \& } \\
\text { Kendall (2002) }\end{array}$ & $\begin{array}{l}\text { Analysis Phase: [subdivided into three phases] [pp. 10-12] } \\
\text {... "identifying problems, opportunities and objectives" } \\
\text {..."determining information requirements for the particular users } \\
\text { involved" } \\
\text {... "analyzing system needs" [using tools such as data flow diagrams } \\
\text { and data dictionaries]. }\end{array}$ \\
\hline
\end{tabular}




\begin{tabular}{|l|l|}
\hline & $\begin{array}{l}\text { Design Phase: The design phase includes: } \\
\ldots \text { logical design of the information system } \\
\ldots \text { data entry procedures } \\
\ldots \text { user interface design } \\
\ldots \text { file or database design } \\
\ldots \text { controls and backup procedures. [pp. 12-13] }\end{array}$ \\
\hline
\end{tabular}

Better communication between business and IT professionals. There is widespread agreement about the importance of user involvement in system development and maintenance, yet the level and quality of user involvement is often inadequate. Users often have difficulty saying what they want. Even if the software totally reflects what they requested, it often omits important capabilities that they failed to request. At a different organizational level, but in a similar vein, misalignment between business and IT is an ongoing source of frustration and inefficiency. As reported in MIS Quarterly Executive, annual surveys of IT executives in the Society for Information Management (SIM) in 2003, 2004, and 2005 all identified "IT and business alignment" as the \#1 management concern. (Luftman \& Mclean, 2003; Luftman, 2004; Luftman et al, 2005) The 2003 and 2005 surveys asked about key enablers and inhibitors of alignment. For both years, the \#1 enabler was "IT understands the firm's business environment." In 2005, the \#1 inhibitor was "business communication with IT."

These issues have been discussed for several decades and the same issues will surely appear for years to come. Using the proposed definition of information systems and everything that follows from it (e.g., the work system framework and work system life cycle model) could help in attaining a mutual understanding of how systems should be improved. This might be an approach for improving the efficiency and quality of collaboration between business and IT professionals. Obviously it is necessary to compile details needed for programming and software configuration. However, many business professionals find it difficult to discuss software-related details that are not directly linked to their everyday work. In addition, IT-centered discussions may miss many important big picture issues that can engage business professionals and that should be discussed before launching into technical details. For example, jumping quickly to "tell me what you want this software to do" might miss big picture issues such as whether current processes and activities are too structured or not structured enough, whether processes and activities are too complex or not complex enough, and whether the rhythm of the work might change for the better. Improvements at the detailed level may yield only marginal results if big picture issues that would have been revealed through the proposed IS definition are never discussed.

Systems analysis and design methods for business professionals. One of the main causes of the abysmal rate of disappointment and failure in IT projects is inadequate user involvement in the early stages of these projects. For example, in the Standish Group's biennial survey of thousands of projects, "lack of user involvement traditionally has been the number one reason for project failure. Conversely, the number one contributor to project success has been user involvement. Even when delivered on time and on budget, a 
project can fail if it does not meet user needs or expectations." (Johnson et al, 2001) Markus \& Mao's (2004) much more nuanced and detailed survey of the current understanding of user participation proposes that the quality of engagement by business professionals is important because "[user] participation richness is related to [both] solution development and solution implementation success.” (p. 535).

There is little or no evidence that existing systems analysis and design methods for IT professionals are effective tools for business professionals working without the direct support of IT professionals. Discussions at conferences usually find substantial agreement about the difficulty of teaching techniques such as data flow diagrams and entity relationship diagrams to non-technical business students in introductory IS courses. Discussions questioning whether UML is used effectively by IT professionals (e.g., Erickson \& Siau (2004), Dobing \& Parsons (2006)) give inconsistent results about how UML is used and the extent to which it is used by IT professionals. It seems quite unlikely that it is an appropriate tool for direct use by typical business professionals, even if they can understand verbal explanations of use case diagrams that have been produced for them. The work system method and other methods with greater sociotechnical content and closer association with the proposed IS definition might lead to better results.

Keeping the customer in sight. Given that just about everyone agrees (or at least claims publicly) that organizations exist to serve their customers and that the customer comes first (or at worst second), it would be good if a definition of information system helped in keeping customers in sight. The proposed definition does exactly that.

Defining an information system as a work system devoted to processing information keeps the customer in sight because work systems exist to produce products and services for internal and/or external customers. The form and content of the work system framework (Figure 2 in the Appendix) emphasize the importance of customers by placing the customers at the top and showing that the purpose of the system's processes and activities is to produce products and services for customers.

Going a step further, the elements of a work system can be used as a basis for evaluating the customer-centricity of any work system (or information system) and for adjusting the system to attain the right degree of customer-centricity. The idea of customer-centricity has become commonplace, but is often vague. The classification of an information system as customer-centric or not is far less important than the use of dimensions of customer-centricity to respond to customer needs. Table 6 shows how work system elements point to 12 dimensions of customer-centricity. Any existing or proposed information system can be evaluated along each of these dimensions (e.g., on a scale from 0 to 3 ) as part of the effort to find the appropriate tradeoffs between various aspects of customer-centricity and other important design factors. (Alter, 2007c) 
Table 6 Dimensions of customer-centricity in work systems

\begin{tabular}{|l|l|l|}
\hline $\begin{array}{l}\text { Work system } \\
\text { element }\end{array}$ & \multicolumn{1}{c|}{ Dimension } \\
\hline Customer & $\bullet \begin{array}{l}\text { Recognizing and responding fully to customer needs } \\
\text { - Providing a satisfying customer experience }\end{array}$ \\
\hline $\begin{array}{l}\text { Products and } \\
\text { services }\end{array}$ & $\bullet$ & Producing customized products and services \\
\hline $\begin{array}{l}\text { Processes } \\
\text { and activities }\end{array}$ & $\bullet \begin{array}{l}\text { Personalizing or customizing processes and activities } \\
\text { Using customer information to maximize benefits for customers } \\
\text { Relying on co-production or self-service by customers }\end{array}$ \\
\hline Participants & $\bullet \begin{array}{l}\text { Non-customer participants recognize and emphasize customer needs } \\
\text { and priorities }\end{array}$ \\
\hline Information & $\bullet \begin{array}{l}\text { Availability of customer-related information to maximize benefits for } \\
\text { customers }\end{array}$ \\
\hline Technology & $\bullet \begin{array}{l}\text { For any technology used by customers, personalization or conformity } \\
\text { to customer work practices, standards, terminology, convenience, or } \\
\text { tastes. }\end{array}$ \\
\hline Infrastructure & $\bullet \begin{array}{l}\text { Avoidance of interfering with or operating incompatibly with relevant } \\
\text { aspects of the customer's infrastructure. }\end{array}$ \\
\hline Environment & $\bullet \begin{array}{l}\text { Operating consistent with the customer's environment wherever the } \\
\text { customer is involved with co-production }\end{array}$ \\
\hline Strategy & $\bullet \begin{array}{l}\text { Producing products and services that are consistent with the } \\
\text { customer's strategies. }\end{array}$ \\
\hline
\end{tabular}

Elevating the centrality of service and service metaphors in the IS field. Services comprise nearly $75 \%$ of the U.S. economy (Horn 2005). Recognizing the large percentage of its revenues that services produce, IBM has promoted a major initiative to encourage the development of "services science" along with the development of instructional programs in SSME (services science, management, and engineering). The July 2006 edition of the Communications of the ACM contained a special section on services science that included 13 papers such as Chesbrough \& Spohrer (2006), Bitner \& Brown (2006), and Maglio et al (2006). Editorial notes in Information Systems Research (Rai \& Sambamurthy, 2006) covered similar territory with special emphasis on opportunities for IS scholars.

The existing IS field focuses on services in a variety of ways. All systematic services are produced through service systems that rely on information systems, and in many cases are tightly integrated with information systems that exist within or across organizations. IT groups often think and speak of IT users as customers. SERVQUAL, a multi-item scale developed to assess customer perceptions of service quality in service and retail businesses (Parasuraman et. al, 1985) has been applied to services provided by IT groups (See Association for Information Systems (2008)). On the technical side, the traditional concept of client-server has developed into service-oriented architecture (SOA) and 
extensive discussions of service-oriented enterprises (SOE) and service-oriented infrastructures (SOI).

Given the groundswell of attention to services, it might be beneficial for the IS field to elevate the centrality of service concerns and service metaphors. The content of the proposed IS definition and the form of the work system framework (Figure 2 in the Appendix) directly support that type of thrust. Greater attention to service systems in the IS field would place greater emphasis on customer value, the customer experience, and the customer's shared responsibility for producing whatever a work system produces and attaining value from it. It might also develop bridges between social and technical views of service. An integrated view of service in IS field might lead to new types of systems analysis and new insights for research about how IT-reliant work systems and organizations operate. (See Alter (2007a, 2008) for steps in that direction.)

\section{Conclusion}

This paper addressed the fifth of Paul's (2007) five challenges by answering the question "What is an Information System?' He said that 'since many people are studying IS from a variety of perspectives, maybe it should be no surprise that there are a variety of definitions. But then, how would Society know what IS is and what it can do if there is no clear understanding?"

Addressing all five challenges. The IS definition offered in response to Paul's fifth challenge might lead to responses to his other four challenges as well:

"1. Nobody knows who we are outside of the IS community."

Response: Do things that are of greater interest outside of the IS community. The proposed IS definition links directly to many different fields. It does the opposite of encouraging us to focus tightly on arcane, and often transient, issues within the IS discipline.

"2. Demand for students to study IS is generally dropping, and it is particularly rapid in the U.S.A."

Response: The definition leads toward broadening the IS field's appeal by making it more understandable to most business professionals and students. Instead of hunkering down and focusing closely on a more limited set of topics, this may involve broadening and establishing alliances with other fields.

"3. Research publications in IS do not appear to be publishing the right sort or content of research." 
Response: Addressing this assertion is beyond this paper's scope. However, the proposed definition, and the linkage to other fields might result in research that is more related to real world situations.

4. "Journal League Tables" (pressure to publish in a very small number of journals)

Response: Proceeding with the broad view of IS implied by the proposed IS definition might encourage the development of new content, new journals and new types of publications that address information system issues more broadly.

Comparison with alternative definitions. In addition to presenting the proposed definition, this paper included in Table 1 a lengthy list of alternative IS definitions. Comparing the scope and relative benefits of the proposed definition and the other definitions is beyond this paper's scope and surely beyond the patience of readers. Nonetheless, this paper's discussion of concepts and understandings that follow from the proposed definition presents a challenge for any other definition. A better definition should have substantial advantages over the proposed definition in terms of simplicity, clarity, scope, systematic power, explanatory power, validity, reliability, and fruitfulness.

Advantages of the proposed definition. Suffice it to say that the proposed IS definition is very general and has a large number of advantages:

- It is understandable.

- It leads to and organizes a layered set of concepts that can be used to summarize existing and proposed systems and to analyze those systems in some depth. (See the Appendix.)

- It provides a basis for communication between business and IT professionals and between IS researchers who focus on different aspects of the IS field using different methods.

- Potentially, it could help in cataloguing past research and developing a body of knowledge for the IS field.

- Potentially it could help in explaining the IS field to Society.

- Potentially it could lead to new developments and extensions of the IS field.

This paper showed that merely providing a definition or meaningful list of topics is not sufficient. In addition to covering the current IS field, an IS definition that matters needs to motivate insights and research about important questions and problems. It should help practitioners and educators. It should provide direction for researchers. The paper's coverage of a wide range of topics demonstrates that the proposed IS definition has many beneficial characteristics and leads in many potentially fruitful directions. A better 
alternative should rate comparably in terms of the evaluation criteria and should have other advantages that the proposed definition lacks.

\section{About the author}

Steven Alter is Professor of Information Systems at the University of San Francisco. He earned a Ph.D. from MIT and extended his thesis into one of the first books on decision support systems. He served for eight years as Vice President of Consilium, a manufacturing software firm that went public in 1989 and was acquired by Applied Materials in 1998. His research for the last decade has concerned developing systems analysis concepts and methods that can be used by typical business professionals and can support communication with IT professionals. His 2006 book, The Work System Method: Connecting People, Processes, and IT for Business Results, is a distillation and extension of ideas in 1992, 1996, 1999, and 2002 editions of his information system textbook. His articles have been published in Harvard Business Review, Sloan Management Review, MIS Quarterly, IBM Systems Journal, European Journal of Information Systems, Decision Support Systems, Interfaces, Communications of the ACM, Communications of the AIS, CIO Insight, and many conference proceedings.

\section{References}

ACKOFF RL Presentation at the Systems Thinking in Action Conference, Cambridge, MA, cited by SILVER M, MARKUS ML and BEATH CM (1995) The Information Technology Interaction Model: A Foundation for the MBA Core Course," MIS Quarterly (19)3, 361-390.

AGARWAL R and LUCAS HC, JR. (2005) The Information Systems Identity Crisis: Focusing on High-Visiblity and High-Impact Research, MIS Quarterly, 29(3), 381-398.

ALTER S (1999a) A General, but Useful Theory of Information Systems, Communications of the AIS 1(13), http://cais.aisnet.org/articles/default.asp?vol=1\&art=13 .

ALTER S (1999b) Information Systems: A Management Perspective, $3^{\text {rd }}$ ed., Prentice Hall, Upper Saddle River, NJ.

ALTER S (2000) Same Words, Different Meanings: Are Basic IS/IT Concepts Our SelfImposed Tower of Babel? Communications of the Association for Information Systems, 3(10), http://cais.aisnet.org/articles/default.asp?vol=3\&art=10

ALTER S (2003a) 18 Reasons Why IT-Reliant Work Systems Should Replace 'The IT Artifact' as the Core Subject Matter of the IS Field, Communications of the Association for Information Systems, 12 (23), 365-394. http://cais.aisnet.org/articles/default.asp?vol=12\&art=23

ALTER S (2003b) Sidestepping the IT Artifact, Scrapping the IS Silo, and Laying Claim to 'Systems in Organizations,' Communications of the Association for 
Information Systems, 12(30), 494-526,

http://cais.aisnet.org/articles/default.asp?vol=12\&art=30

ALTER S (2004) Desperately Seeking Systems Thinking in the IS Discipline, Proceedings of ICIS-25, the International Conference on Information Systems, Washington, DC, 757-769.

ALTER S (2005) Architecture of Sysperanto - A Model-Based Ontology of the IS Field, Communications of the Association for Information Systems, 15(1), 1-40. http://cais.aisnet.org/articles/default.asp?vol=15\&art=1

ALTER S (2006) The Work System Method: Connecting People, Processes, and IT for Business Results, Work System Press, Larkspur, CA.

ALTER S (2007a) Service Responsibility Tables: A New Tool for Analyzing and Designing Systems, AMCIS 2007 - Americas Conference on Information Systems, Keystone, CO.

ALTER S (2007b) Pitfalls in Analyzing Systems in Organizations, Journal of Information System Education, 17(3), 295-302.

ALTER S (2007c) Customer-Centric Systems: A Multi-Dimensional View, Proceedings of WeB 2007, Sixth Workshop on eBusiness, Montreal, Canada, 130-141.

ALTER S (2008) “Service System Fundamentals," IBM Systems Journal 47(1), 71-85. http://www.research.ibm.com/journal/sj/471/alter.html

ASSOCIATION FOR INFORMATION SYSTEMS (2008) Theories in IS Research.

Web site viewed on Feb. 2, 2008 at http://www.istheory.yorku.ca/

AVISON DE and MYERS MD Avison (1995) Information systems and anthropology: an anthropological perspective on IT and organizational culture. Information Technology \& People, 8(3), 43-46.

BENBASAT I and ZMUD RW (2003) The Identity Crisis within the IS Discipline: Defining and Communicating the Discipline's Core Properties. MIS Quarterly, 27(2), 183-194.

BITNER MJ and BROWN SW (2006) "The Evolution and Discovery of Services Science in Business Schools," Communications of the ACM 49(7) 73-79.

BOSTROM RP and HEINEN JS (1977a) MIS Problems and Failures: A SocioTechnical Perspective. PART I: The Causes." MIS Quarterly, 1(3), 17-32.

BOSTROM RP and HEINEN JS (1977b) MIS Problems and Failures: A SocioTechnical Perspective. PART II: The Application of Socio-Technical Theory. MIS Quarterly, 1(4), 11-28.

BRYNJOLFSSON E (2003) The IT Productivity Gap, Optimize, 21, http://ebusiness.mit.edu/erik/Optimize/pr_roi.html

BUCKINGHAM RA, HIRSCHHEIM RA, LAND FF and TULLY CJ eds., Information Systems Education: Recommendations and Implementation. Cambridge University Press, Cambridge, UK, 204-214

CARR N (2003) IT Doesn't Matter, Harvard Business Review, 81(5) 41-49.

CARVALHO JA (2000) Information System? Which One Do You Mean? in FALKENBERG E, LYYTINEN K and VERRIJN-STUART eds., Information Systems Concepts: An Integrated Discipline Emerging, Proceedings of the ISCO 4 Conference, Leiden, Holland, 20 -22 September 1999), Kluwer.Academic Publishers, 259-280. viewed on Feb. 1, 2008 at http://piano.dsi.uminho.pt/ jac/SI/zdocumentos/IS1234.pdf 
CHECKLAND P (1999) Systems Thinking, Systems Practice (Includes a 30-year retrospective), John Wiley \& Sons, Chichester, UK.

CHECKLAND P and HOLWELL S (1998) Information, Systems, and Information Systems: making sense of the field. John Wiley \& Sons, Chichester, UK.

CHESBROUGH H and SPOHRER J (2006) A research manifesto for services science, Communications of the ACM, 49(7), 35-40.

DAVIS GB (1974) Management Information Systems: Conceptual Foundations, Structure, and Development, McGraw-Hill Book Company, New York.

DAVIS GB (2000) Information Systems Conceptual Foundations: Looking Backward and Forward, 61- 82 in BASKERVILLE R, STAGE J and DEGROSS JI, eds., Organizational and Social Perspectives on Information Technology, Springer

DAVIS LE and TAYLOR JC, eds. (1979) Design of Jobs, $2^{\text {nd }}$ ed., Goodyear Publishing Company, Santa Monica, CA.

DELONE WH and MCLEAN ER (1992) Information systems success: the quest for the dependent variable, Information Systems Research, 3(1), 60-95.

DELONE WH and MCLEAN ER (2003) The DeLone and McLean Model of Information Systems Success, Journal of Management Information Systems 19(4), 9-30.

DENNIS AB, WIXOM H and TEGARDEN (2002) Systems Analysis \& Design: An Object Oriented Approach with UML, John Wiley \& Sons, New York, NY.

DOBING B and PARSONS J (2006) How the UML Is Used, Communications of the ACM, 49(5), 109-113.

ERICKSON J and SIAU K (2004) Theoretical and Practical Complexity of UML, Proceedings of the Tenth Americas Conference on Information Systems, New York, New York, 1669-1674.

FALKENBERG ED, HESSE W, LINDGREEN P, NILSSON BE, OEI JLH, ROLLAND C, STAMPER RK, VAN ASSCHE FJM, VERRIGN-STUART AA and VOSS K (1998) A Framework of Information System Concepts: The FRISCO Report, IFIP, ISBN 3-

901882-01-4, viewed on Sept. 22008 at http://www.mathematik.unimarburg.de/ hesse/papers/fri-full.pdf

FICHMAN RG and KEMERER, CF (1999) The Illusory Diffusion of Innovation: An Examination of Assimilation Gaps, Information Systems Research, 10 (3), 255-275.

FREEMAN P and SEDDON PB (2004) Factors Affecting the Realisation of Benefits from CRM Packaged Software based Work Systems, Proceedings of PACIS, the Pacific Asia Conference on Information Systems 1765-1778.

GRAY P (2006) Manager's Guide to Making Decisions about Information Systems, John Wiley \& Sons, Boston, MA.

HILL C, YATES R, JONES C and KOGAN SL (2006) Beyond predictable workflows: Enhancing productivity in artful business processes, IBM Systems Journal, 45(4), 663-682.

HIRSCHHEIM R and KLEIN HK (1994) Realizing Emancipatory Principles for Information Systems Development: The Case for ETHICS, MIS Quarterly, 18(1), 83-109.

HIRSCHHEIM R and KLEIN HK (2003) Crisis in the IS Field? A Critical Reflection on the State of the Discipline, Journal of the Association for Information Systems, 4(5), 237-293. 
HOFFER JA, GEORGE JF, and VALACICH JS (2002) Modern Systems Analysis \& Design, Prentice Hall, Upper Saddle River, NJ.

HORN P (2005) The New Discipline of Services Science, BusinessWeek, viewed on Sept. 1, 2008 at http://www.businessweek.com/technology/content/jan2005/tc20050121_8020.htm,

HUBER MW, PIERCY CA and MCKEOWN PG (2007) Information Systems: Creating Business Value, John Wiley \& Sons, Hoboken, NJ.

JÄRVELIN K. and WILSON TD (2003) On conceptual models for information seeking and retrieval research Information Research, 9(1), paper 163 viewed on Sept 1, 2008 at http://InformationR.net/ir/9-1/paper163.html]

JASPERSON J, CARTER PE and ZMUD RW (2005) A Comprehensive Conceptualization of Post-Adoptive Behaviors Associated with Information Technology Enabled Work Systems, MIS Quarterly, 29(3), 525-557.

JESSUP L and VALACICH J (2008) Information Systems Today: Managing in the Digital World, $3^{\text {rd }}$ ed., Pearson Prentice Hall, Upper Saddle River, NJ.

JOHNSON J, BOUCHER KD, CONNORS K and ROBINSON J (2001) Collaborating on Project Success," Sponsored Supplement, Software Magazine, viewed on Feb. 2, 2008 at http://www.softwaremag.com/archive/2001feb/CollaborativeMgt.html

KENDALL KE and KENDALL JE (2002) Systems Analysis and Design, $5^{\text {th }}$ ed., Prentice Hal, Upper Saddle River, NJ.

KROENKE DM (2008) Experiencing MIS, Pearson Prentice Hall, Upper Saddle River, NJ.

LAND F (1985) Is an Information Theory Enough?, The Computer Journal, 28(3), 211-215.

LAND F (2000) Evaluation in a Socio-Technical Context, Proceedings of IFIP W.G.8.2 Working Conference 2000, IS2000: The Social and Organizational Perspective on Research and Practice in Information Systems, Aalberg, Denmark.

LAUDON KC and LAUDON JP (2007) Management Information Systems: Managing the Digital Firm, $10^{\text {th }}$ ed., Pearson Prentice-Hall, Upper Saddle River, NJ.

LUFTMAN J and MCLEAN ER (2004) Key Issues for IT Executives," MIS Quarterly Executive, 3(2), 89-104.

LUFTMAN J (2005) Key Issues for IT Executives for 2004, MIS Quarterly Executive, 4(2), 269-285.

LUFTMAN J KEMPAIAH R and NASH E (2006) Key Issues for IT Executives 2005, MIS Quarterly Executive, 5(2), 27-45.

LYYTINEN K and NEWMAN M (2006) Punctuated Equilibrium, Process Models and Information System Development and Change: Towards a Socio-Technical Process Analysis, Sprouts: Working Papers on Information Environments, Systems, and Organizations, 6(1), 1-48, viewed on Sept. 1, 2008 at http://sprouts.case.edu/2006/060101.pdf

MAGALHÃES R (1999) Organizational Implementation of Information Systems: towards a new theory., Ph.D. Thesis, London School of Economics. http://www.lse.ac.uk/collections/informationSystems/pdf/theses/magalhaes.pdf

MAGLIO PP, SRINIVASAN S, KRUELEN JT and SPOHRER J (2006) Service Systems, Service Scientists, SSME, and Innovation, Communications of the ACM, 49(7), 81-85. 
MARKUS ML and MAO JY (2004) Participation in Development and Implementation - Updating an Old, Tired Concept for Today's IS Contexts, Journal of the Association for Information Systems, 514-544.

MATHIASSEN LA, MUNK-MADSEN PA, NIELSEN PA and STAGE J (2000) Object Oriented Analysis \& Design, Marko Publishing, Aalborg, Denmark.

MCLEOD R, JR. and SCHELL GP (2007) Management Information Systems, $10^{\text {th }}$ ed., Pearson Prentice-Hall, Upper Saddle River, NJ.

MITCHELL VL and ZMUD RW (1999) The Effects of Coupling IT and Work Process Strategy in Redesign Projects, Organization Science, (10)4, 424-438.

MUMFORD E and WEIR M (1979) Computer systems in Work Design - the ETHICS method, John Wiley \& Sons, New York.

MUMFORD E (2000) Socio-technical Design: An Unfulfilled Promise? Proceedings of IFIP W.G.8.2 Working Conference 2000, IS2000: The Social and Organizational Perspective on Research and Practice in Information Systems, Aalberg, Denmark..

O'BRIEN JA (2003) Introduction to Information Systems: Essentials for the e-Business Enterprise, $11^{\text {th }}$ ed. McGraw Hill - Irwin, Boston, MA.

ORLIKOWSKI WJ (1993) CASE Tools as Organizational Change: Investigating Incremental and Radical Changes in Systems Development, MIS Quarterly, 17(3), 309-340.

ORLIKOWSKI WJ and IACONO CS (2001) Research Commentary: Desperately Seeking the "IT" in IT Research - A Call to Theorizing the IT Artifact Information Systems Research, 12(2), June 2001, 121-134.

PARASURAMAN A, BERRY LL and ZEITHAML VA (1985) A Conceptual Model of Service Quality and Its Implications for Future Research, Journal of Marketing, 49(4), 41-50.

PASMORE WA (1985) Social Science Transformer: the Socio-technical Perspective, Human Relations. (48)1, 1-22.

PAUL RJ (2007) Challenges to information systems: time to change, European Journal of Information Systems, 16(3), 193-195.

PAWLAK Z (2002) Rough sets and intelligent data analysis, Information Sciences, 147, $1-12$

PETRIE DE (2004) Understanding the Impact of Technological Discontinuities on Information Systems Management: The Case of Business-to-Business Electronic Commerce, Ph.D. Thesis, Claremont Graduate University.

PETKOV D and PETKOVA O (2006) The Work System Model as a Tool for Understanding the Problem in an Introductory IS Project, Proceedings of the $23^{\text {rd }}$ Information Systems Education Conference (ISECON 2006), Dallas, TX.

RAI A and SAMBAMURTHY V (2006) Editorial Notes - The Growth of Interest in Services Management: Opportunities for Information System Scholars, Information Systems Research 17(4) 327-331.

RAINER RK, TURBAN E and POTTER RE (2007) Introduction to Information Systems, John Wiley \& Sons.

RALPH P and WAND Y (2007) An Ontology of Design Concepts," working paper presented at the Theory Development Workshop of the Journal of the Association of Information Systems," Montreal, Canada, Dec. 12, 2007. 
RAMILLER N (2002) Animating the Concept of Business Process in the Core Course in Information Systems, Journal of Informatics Education and Research, 3(2), 5371. viewed on Sept. 12008 at http://iaim.aisnet.org/jier/V3N2/

SCHRAGE M (2005) IT's Hardest Puzzle, CIO Magazine, (blog) Aug. 9. Viewed on Feb. 1, 2008 at http://www.cio.com.au/index.php/id;1031171136

SHERER SA and ALTER S (2004) Information System Risks and Risk Factors: Are They Mostly about Information Systems? Communications of the Association for Information Systems," 14(2), 29-64.

SIAU K, SHENG H and NAH FF-H (2004) The Value of Mobile Commerce to Customers, Proceedings of the Third Annual Workshop on HCI Research in MIS, Washington D.C., 65-69.

SUMNER M and RYAN T (1994) The Impact of CASE: Can It Achieve Critical Success Factors? Journal of Systems Management, (45)6, 16-21.

SYMONS VJ (1991) Impacts of Information Systems: Four Perspectives, Information and Software Technology, 33(3), 181-190.

TADEUSZ L and RYBNIK J (1992) Rough Sets and Some Aspects of Logic Synthesis, 181- 201 in SLOWINSKI R, ed., Intelligent Decision Support: Handbook of Applications and Advances of the Rough Sets Theory," Springer, 1992

TECHWEB (2008) "information system" in TechEncyclopedia, viewed on Feb. 1, 2008. http://www.techweb.com/encyclopedia/defineterm.jhtml?term=information+syste $\underline{\mathrm{m}}$

TRIST E (1981) The Evolution of socio-Technical Systems: A Conceptual Framework and an Action Research Program." in Van de Ven and W. Joyce, Perspectives on Organizational Design and Behavior, NY:Wiley Interscience, 1981

UNITED KINGDOM ACADEMY FOR INFORMATION SYSTEMS (UKAIS) (1997), Newsletter of the UKAIS 3, cited by MONARCH IA "Information Science and Information Systems: Converging or Diverging? Viewed on Sept. 1, 2008 at http://www.cais-acsi.ca/proceedings/2000/monarch_2000.pdf

WAND Y and WEBER R (1990) Toward a Theory of the Deep Structure of Information Systems, in DEGROSS J, ALAVI M and OPPELLAND H, eds., Proceedings of the Eleventh International Conference on Information Systems, Copenhagen, Denmark, 61-71.

WAND Y and WEBER R (2002) Research Commentary: Information Systems and Conceptual Modeling - A Research Agenda, Information Systems Research, 13(4), 363-376.

WATSON RT, ed., (2008) Information Systems. Release 6, Global Text Project, viewed on Sept. 1, 2008 at http://homepage.mac.com/rickwatson/filechute/IS\%20bookE1R6.pdf

\section{Appendix: Background Related to the Work System Approach}

This Appendix covers topics that have been presented in various evolving versions over the last decade: 
- summary of the work system framework

- clarifications about each of the elements of a work system

- summary of the work system life cycle model

- summary of the work system method.

\section{Work System Framework}

The work system framework (Figure 2) was developed to help business professionals recognize and understand IT-reliant systems in organizations. This framework emphasizes business rather than IT concerns. It identifies nine elements that are part of even a rudimentary understanding of a work system. (Alter, 2003a; 2004; 2006; 2008) Six of those elements are part of the definition of information system. The three additional elements are included because they are an important part of even a rudimentary understanding of a work system, and hence an information system.

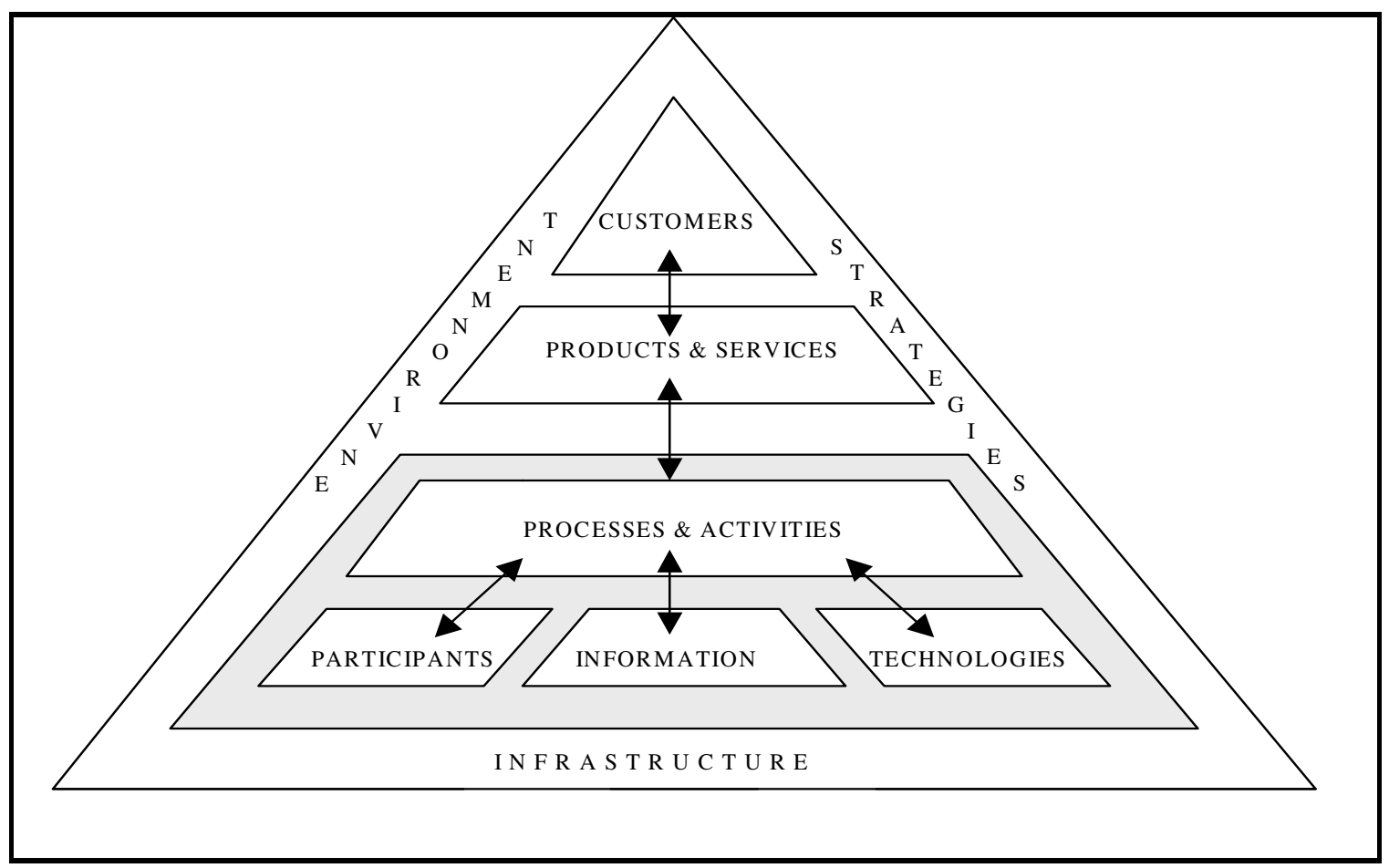

Figure 2. The Work System Framework (slightly updated). (Alter, 2007a; 2008)

The work system framework provides an outline for describing the system being studied, identifying problems and opportunities, describing possible changes, and tracing how those changes might affect other parts of the work system. The arrows within the framework indicate that the various elements of a work system should be in balance. The 
first four elements are the basic components that actually perform the work. These include processes and activities, participants, information, and technologies.

The work system framework assumes that customers and products and services are not part of a work system; it includes those two elements because systems exist in organizations in order to produce products and services for internal or external customers. Environment and infrastructure are included in the work system framework because a work system's success often depends on its fit with the surrounding environment and on its use of available infrastructure that is shared with other work systems. Strategies are included in the framework as a reminder that work systems have implicit or explicit strategies and that those strategies should be aligned with the organization's strategies.

The framework makes no assumptions about whether or not IT is used. It simply reserves a location for whatever technology is used. This is appropriate because any particular work system might not use IT, or might use IT only in a minor way. Furthermore, the framework does not create an artificial separation between the work system that produces products and services for the customer and the information system that often overlaps with the work system. Regardless of whether the topic is an information system or an ITreliant work system that is supported by an information system, it is the analyst's responsibility to decide the content and boundaries of the system of interest.

The framework says nothing about how long a system will exist. Some work systems exist and produce their outputs over extended time spans. Others are projects, temporary systems designed to produce a particular output and then dissolve. In other words, the same framework can be used to summarize work systems in general, information systems, and projects. The concept of work system therefore provides a consistent starting point for thinking about work systems in general, about information systems that support work systems, and about projects that build or modify work systems.

The work system framework is easy to understand as an abstraction and has many uses in practice. At the beginning of an analysis it can help people agree about the scope of the system, and hence, what the analysis should include or exclude. Later, it is a useful reference point for keeping the analysis on target and recognizing whether the initial definition of the system and problem proves inadequate in relation to the realities that are uncovered.

The individual ideas underlying the work system framework are not revolutionary, but the framework combines these ideas to provide an organizing perspective that is quite different from the way people in many organizations talk and think about computerized systems. Unless a work system approach or some other consciously sociotechnical approach is taken, informal conversations, formal presentations, and written proposals and documentation about systems often tend to emphasize computerized features and functions. At the same time they tend to de-emphasize how people produce the work system's products with the help of technology, how people deal with exceptions and workarounds, how well the various components of the work system are expected to operate, and how infrastructure and surrounding environment affect the work system. 


\section{More about Work System Elements}

A number of distinctions in the work system framework are useful in understanding work systems. And since information systems are work systems, the same distinctions stated in terms of work systems in general also apply to information systems.

Customers include the direct beneficiaries of whatever a work system produces, plus other customers whose interest and involvement is less direct. This definition includes both internal and external customers, and therefore is less like a marketing definition and more like an operations management or Six Sigma definition. Customers may also be participants, both in self-service situations and in other work systems in which they play a significant co-production role.

As introduced in discussions beyond the scope of this paper, an additional framework called the service value chain framework (Alter 2007a, 2008) is based on the assumption that services tend to be co-produced by providers and customers, implying that customers should be viewed as part of a work system. Since most work systems can be viewed as service systems (Alter 2007a, 2008), at least some of the customers should also be considered participants, even in work systems that are not viewed as self-service systems. (Self-service systems are work systems in which a service provider provides resources that are used by customers to create value for themselves and possibly for the provider.)

Products and services produced by a work system are the combination of physical things, information, and services that the work system produces for its various customers. A work system's products and services may take various forms, including physical products, information products, services, intangibles such as enjoyment and peace of mind, and social products such as arrangements, agreements, and organizations.

Processes and activities cover a full range of situations that might involve highly structured workflows and/or "artful processes" whose sequence and content "depend on the skills, experience, and judgment of the primary actors." (Hill, et al 2006) Perspectives for thinking about processes and activities in depth include workflow, decision making, communication, coordination, control, and information processing, among others. Each of these perspectives brings a distinct set of concepts and generalizations.

Participants are people who perform the non-automated work in the work system. The term participants (not users) is included because non-users of IT may play important roles in work systems, and because the usage of technology is of secondary importance to important participants in many work systems.

Information includes codified and non-codified information used and created as participants perform their work. Typical codified information is the pre-defined information used in tracking packages, entering orders, and performing repetitive 
financial transactions. In each case, each data item must be defined precisely, and the information is often processed using explicit rules. Typical uncodified information includes computerized or handwritten documents, verbal agreements, and formal or informal conversations. Information not related to the work system is not directly relevant, making the common distinction between data and information secondary when describing or analyzing a work system.

Technologies (not IT) is included because multiple technologies may be relevant to the analysis. Technologies may be general purpose or tailored to a specific situation. Technologies tailored to specific business situations usually involve a combination of general-purpose tools and specialized techniques. The separation between tools and techniques is worth considering because it is often possible to use a different generalpurpose tool without changing the technique and vice versa.

Infrastructure includes human, information, and technical resources that the work system relies on even though these resources are managed outside of it and are shared with other work systems.

Environment includes the organizational, cultural, competitive, technical, and regulatory environment within which the work system operates. Factors in the environment affect system performance even though the system may not rely on those factors directly in order to operate. The organization's general norms of behavior are part of the culture in the environment that surrounds the work system, whereas behavioral norms and expectations about specific activities within the work system are considered part of its processes and activities.

Strategies consist of the guiding rationale and high-level choices within which a work system, organization, or firm is designed and operates. A work system's strategy includes its production strategy and its value propositions for customers. Other strategies of relevance for understanding a work system include the business strategies of the organization or firm and technical strategies such as enterprise architectures (if used).

\section{Work System Life Cycle Model}

In addition to leading to a framework for describing and analyzing an information system as it exists at a particular point in time, the proposed definition also leads to the work system life cycle (WSLC) model (Alter 2006). That model describes how persistent work systems (work systems that are not projects) change over time through a combination of planned change (explicit projects with initiation, development, and implementation phases) and unplanned change (adaptations and experimentation). As shown in Figure 3, the WSLC is fundamentally different from the frequently cited system development life cycle (SDLC). First, the SDLC is basically a project model rather than a system life cycle. Even current versions of the SDLC that contain iterations are basically project models. Second, the term system in the acronym SDLC is basically a technical artifact that is being programmed. In contrast, the system in the WSLC is a work system that evolves 
over time through multiple iterations. Unlike control-oriented versions of the SDLC, the WSLC treats unplanned changes as part of a work system's natural evolution.

The WSLC presents a picture of punctuated change (e.g., Lyytinen and Newman, 2006) whereby work systems operate in a fairly stable configuration for extended periods of time, during which work system participants may make minor tweaks and adjustments without changing the fundamental structure or operation of the work system. Eventually management decides to initiate a project that will create a major change in the work system. Punctuated change occurs as the new work system is implemented.

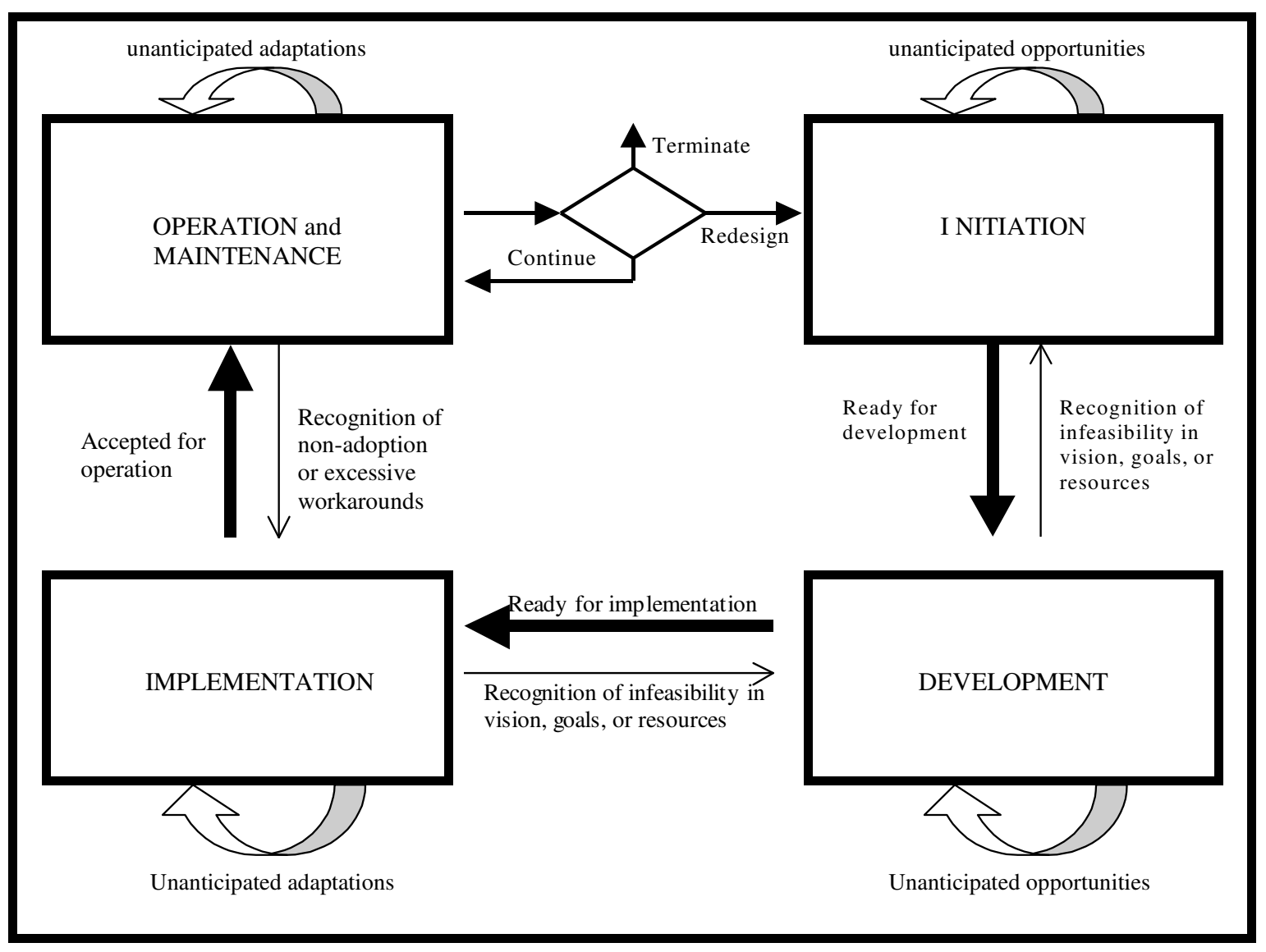

Figure 3. The Work System Life Cycle Model (Alter, 2006)

\section{Work System Method}

The definition of work system (and hence information system) and the two frameworks mentioned above are the basis of the work system method (WSM), an organized way to analyze any work system (and hence any information system) from a business viewpoint. The design of WSM assumes that business professionals frequently lack two important things: first, organized frameworks, terminology, and methods for understanding systems in organizations; second, procedural knowledge about the process of analyzing systems 
and making justified recommendations for improving those systems. The structure and content of WSM attempt to provide both conceptual and procedural knowledge in a readily usable form, and try to express that knowledge in everyday business language. The work system method is organized around the work system framework. Just agreeing on the identity and scope of its nine elements in a particular situation can eliminate fundamental confusions in many situations. (Alter 2006)

WSM is based on the assumption that a single, totally structured analysis method is not appropriate for all situations because the specifics of a situation determine the nature of the understanding and analysis that is required. In some situations, a manager simply wants to ask questions to make sure someone else has done a thoughtful analysis. At other times, a manager may want to establish a personal understanding of a situation before discussing it with someone else. When collaborating with IT professionals, managers can use WSM to clarify and communicate their own understanding of the work system and to make sure that the IT professionals are fully aware of business issues and goals that software improvements should address. Managers and business professionals wishing to perform a thorough analysis can follow a set of specific questions and can use a set of templates for pursuing the analysis in depth. From the other side, IT professionals can use WSM at various levels of detail to confirm that they understand the business professionals who are the customers for their work.

WSM focuses on IT-reliant work systems rather than on IT applications that support them. It is designed to produce shared understandings rather than detailed specifications that are required to produce high quality software. It can be used for existing systems or for totally new systems. Starting with the work system framework and related characteristics and performance indicators, WSM uses business concepts that are readily understandable to business professionals. These concepts are well enough defined to provide a reasonable degree of rigor in the description of the system and in the analysis. WSM's basic form assumes that a set of problems or opportunities motivate the analysis of an existing work system.

The most basic application of WSM encourages the user to think about the situation in work system terms, but provides minimal guidance other than saying that each of three main steps should be included. For example, assume that several people are speaking in general about whether a particular CRM software package might be beneficial. Even if they use WSM in the most basic way they would not focus initially on the features and purported benefits of the CRM software. Instead, they would discuss:

- System and Problem (the SP step): What work system are we talking about? From a business viewpoint, what are the problems and opportunities related to the work system?

- Analysis and Possibilities (the AP step): What are the shortcomings of each part of the work system and what are the possibilities for eliminating or minimizing these shortcomings? Adopting CRM software might be one possible change, but there are probably others.

- Recommendations and Justification (the RJ step): What changes in the work system do we recommend and how could we justify those changes? 
Recognizing the varied goals of WSM applications, WSM can be used at three levels of detail and depth. The user's goals and the need to communicate and negotiate with others determine the level to use in any particular situation.

- Level One: Be sure to remember the three main steps when thinking about a system in an organization: SP (system and problem), AP (analysis and possibilities), and RJ (recommendation and justification).

- Level Two: Within each main step, answer a set of specific questions related to each work system element and other factors that are typically important.

- Level Three: Use checklists, templates, and diagrams to identify and consider topics and issues that might otherwise be overlooked.

In the discussion of CRM, merely using these questions to stay focused on the work system instead of plunging into software details and features would probably make the initial discussion more productive. The discussion would treat the CRM software as part of a larger system. It would be clearer that addressing the business problems or opportunities requires many changes beyond just adopting CRM software.

Executive MBA, MBA, and undergraduate students have used various abbreviated versions with varying degrees of success. The most recent version attained the best balance thus far in terms of excessive simplicity, on the one hand, and excessive completeness and cognitive overload, on the other. Classroom experience plus informal testimonials from employed students (e.g., "I am using it to help in my software sales cycles.") support the possibility that WSM might help business and IT professionals improve current, often unsatisfactory levels of user involvement and business/IT alignment. Field experiments and action research studies are required to learn more about WSM's strengths and limitations and to make it more powerful.

The development of WSM is continuing. New tools based on a new service value chain framework (Alter, 2007a; 2008) will be integrated into WSM to attain greater descriptive and analytical depth and to improve business/IT communication without overloading business professionals with an excessive number of technical distinctions and details. 